\title{
Akad Penerbitan Sukuk di Pasar Modal Indonesia dalam Perspektif Fikih
}

\author{
Eka Nuraini Rachmawati \& Ab Mumin bin Ab Ghani
}

\begin{abstract}
The Contracts of Sukuk Issuances in Indonesian Capital Market from the Fikib Perspectives. This article discusses the concepts of contract in the perspective of Fiqh (Islamic Jurisprudence) and its implementation in Sharia Capital Market, particularly in the issuance of Corporate Sukuk and State Sukuk (SBSN). The purpose of the study is to understand the concept of akad (contract) in Islamic perspective an its implementation in sukuk issuance, mainly related to the transfer of ownership from the sukuk issuer to the investor. This study reveals that the current practice of issuance of corporate sukuk in Indonesia is only based on two models of contracts, namely Ijârah and Mudhârabah contracts. In addition, the contract structure are also varied, depending on the type of the issuer business, the purpose of funding, and the choice of contract. In the future, the issuance of corporate sukuk should have a uniformed, standardized structure, while it still comply with syariah regulation.
\end{abstract}

Keywords: the sukuk, capital market, contract, ijârah, mudhârabah

\begin{abstract}
Abstrak: Akad Penerbitan Sukuk di Pasar Modal Indonesia dalam Perspektif Fikih. Artikel ini membahas konsep akad dalam perspektif Fiqh dan implementasinya di Pasar Modal Syariah, khususnya dalam penerbitan Sukuk Korporasi dan Sukuk Negara (SBSN). Tujuannya untuk mengetahui bagaimana konsep akad dalam perspektif fikih dan implementasinya dalam penerbitan sukuk, terutama berkaitan dengan pemindahan kepemilikan dari penerbit sukuk kepada investor. Penelitian ini menemukan fakta bahwa praktik penerbitan sukuk korporasi di Indonesia saat ini baru menggunakan dua jenis akad, yakni akad Ijârah dan Mudhârabah. Struktur akad tersebut pun berbeda, tergantung pada jenis usaha emiten, tujuan penggunaan dana serta pilihan akad yang paling memungkinkan untuk diterapkan pada saat penerbitan. Di masa datang penerbitan sukuk korporasi mestinya memiliki struktur akad yang baku dan seragam dengan tetap memenuhi aspek kepatuhan syariahnya.
\end{abstract}

Kata Kunci: sukuk, pasar modal, akad, ijârah, mudhârabah

Universitas Islam Riau (UIR) Pekanbaru dan University of Malaya, Malaysia

E-mail: ekanura212@yahoo.co.id \& abmumin@gmail.com 


\section{Pendahuluan}

Akad memiliki peranan sangat penting dalam dunia bisnis, karena keberlangsungan kegiatan bisnis ke depan akan tergantung seberapa baik dan rinci akad yang dibuat untuk menjaga dan mengatur hak dan kewajiban kedua belah pihak yang melakukan akad. ${ }^{1}$ Akad merupakan perjanjian yang mengikat hubungan kedua pihak itu sekarang dan yang akan datang. Pemilihan akad akan mencerminkan seberapa besar risiko dan keuntungan bagi kedua pihak, terutama bagi pihak pemodal maupun pihak yang mengelola bisnis atau antara pembeli dengan penjual.

Ilmu fikih menawarkan berbagai rincian dan penetapan dasar-dasar perjanjian bisnis sehingga dapat merealisasikan tujuan dan kepentingan yang berakad. Selain itu, ilmu fikih khususnya ilmu fikih muamalah akan menjawab persoalan serta membuat aturan untuk menjalankan aktivitas bisnis yang sesuai dengan prinsip syariah serta melahirkan kaidah-kaidah dan pandangan yang digunakan untuk transaksi bisnis yang baru muncul dan semakin beragam di era modern. Semakin jelas, cermat serta rinci dalam membuat akad maka semakin kecil kemungkinan terjadi konflik antar kedua belah pihak yang berakad di masa yang akan datang karena masing-masing pihak memahami hak dan kewajibannya.

Istilah akad berasal dari bahasa Arab yakni al-Aqd. Secara bahasa kata al-Aqd, bentuk masdarnya adalah Aqada dan jamaknya adalah al'Uqûd yang berarti perjanjian (yang tercatat) atau kontrak. ${ }^{2}$ Di dalam

${ }^{1}$ Silakan lihat Muslimin Kara. "Konstribusi Pembiayaan Perbankan Syariah Terhadap Pengembangan Usaha Mikro Kecil dan Menengah (UMKM) di Kota Makasar.” 47, no. 1 (2013). Yuli Andriansyah. "Kinerja Keuangan Perbankan Syariah di Indonesia dan Kontribusinya bagi Pembangunan Nasional." La_Riba 3, no. 2 (2009): h. 181-196. Aziz Budi Setiawan. "Perbankan Syariah; Challenges dan Opportunity Untuk Pengembangan di Indonesia." Jurnal Kordinat 8, no. 1 (2006). Mhd Asaad. "Peningkatan Peranan Perbankan Syariah Untuk Pembiayaan Usaha Pertanian." MIQOT: Jurnal Ilmuilmu Keislaman 35, no. 1 (2011). Dwi Agung Nugroho Arianto. "Peranan Al-Mudharabah sebagai Salah Satu Produk Perbankan Syariah dalam Upaya Mengentaskan Kemiskinan di Indonesia.” Jurnal Ekonomi \& Pendidikan 8, no. 2 (2011). Russely Inti Dwi Permata. "Analisis Pengaruh Pembiayaan Mudharabah dan Musyarakah Terhadap Tingkat Profitabilitas (Return On Equity) (Studi pada Bank Umum Syariah Yang Terdaftar di Bank Indonesia Periode 2009-2012).” Jurnal Administrasi Bisnis 12, no. 1 (2014). Fitriani Prastiawati, dan Emile Satya Darma. "Peran Pembiayaan Baitul Maal Wat Tamwil Terhadap Perkembangan Usaha dan Peningkatan Kesejahteraan Anggotanya dari Sektor Mikro Pedagang Pasar Tradisional." Jurnal Akuntansi dan Investasi 17, no. 2 (2016): h. 197-208.

2 Ahmad Warson Munawwir, Kamus Al-Munawwir Arab-Indonesia Terlengkap (Surabaya: Pustaka Progressif, 1997), h. 953. 
buku Ensiklopedi Hukum Islam, al-'aqd yang memiliki arti perikatan, perjanjian, dan permufakatan (al-ittifâq). ${ }^{3}$ Dalam kaidah fikih, akad didefinisikan sebagai pertalian ijab (pernyataan melakukan ikatan) dan kabul (pernyataan penerimaan ikatan) sesuai dengan kehendak syariat yang berpengaruh kepada objek perikatan sehingga terjadi perpindahan pemilikan dari satu pihak kepada pihak yang lain. ${ }^{4}$ Adapun pengertian akad menurut istilah adalah perikatan antara ijab dengan qabul yang dibenarkan syara' yang menetapkan keridaan kedua belah pihak. ${ }^{5}$

Berdasarkan definisi di atas, dapat dipahami bahwa akad adalah suatu perbuatan yang sengaja dibuat oleh dua orang atau lebih berdasarkan keridaan masing-masing pihak yang melakukan akad dan memiliki akibat hukum baru bagi mereka yang berakad.

Landasan akad mengacu kepada Firman Allah Swt. dalam Alquran, Q.s. al-Mâidah [5]: 1 dan Q.s. al-Nisâ [4]: 29 yang berbunyi:

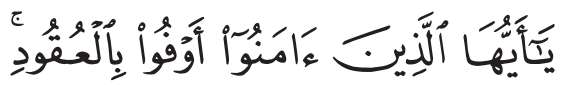

Hai orang-orang yang beriman, penubilah aqad-aqad itu......

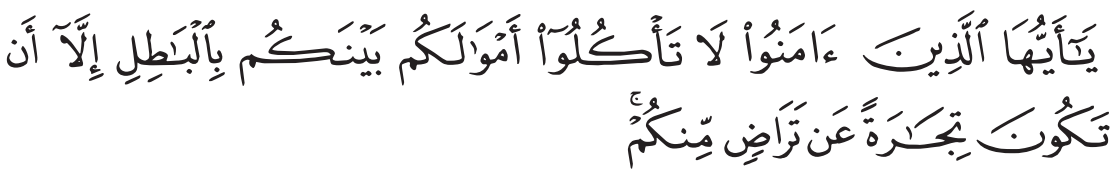

Hai orang-orang yang beriman, janganlah kamu saling memakan harta sesamamu dengan jalan yang batil, kecuali dengan jalan perniagaan yang berlaku dengan suka sama-suka di antara kamu.

Dua ayat tersebut di atas menegaskan bahwa setiap mukmin berkewajiban menunaikan apa yang telah dijanjikan dan diakadkan baik berupa perkataan maupun perbuatan. Pelaksanaan akad dalam transaksi perdagangan diharuskan adanya kerelaan kedua belah pihak, atau yang

${ }^{3}$ Abdul Aziz Dahlan, 'Ensiklopedi Hukum Islam', (Jakarta: Ichtiar Baru Van Hoeve, 1996), h. 63.

${ }^{4}$ Moh Mabruri Faozi and Putri Inggi Rahmiyanti, 'Sistem Pengupahan Tenaga Kerja Home Industri Perspektif Ekonomi Islam', Al-Mustashfa: Jurnal Penelitian Hukum Ekonomi Syariah, 4.1 (2016), h. 107.

5 Masnun Tahir, 'Pemikiran T. M. Hasbi Ash-Shiddieqy: Sumber Hukum Islam dan Relevansinya dengan Pemikiran Hukum Islam di Indonesia', Al-Ahwal: Jurnal Hukum Keluarga Islam, 1.1 (2016), h. 117-52. 
diistilahkan 'an tarâdhin minkum'. Walaupun kerelaan tersebut merupakan sesuatu yang tersembunyi di lubuk hati, tetapi indikator dan tandatandanya dapat terlihat. Ijab dan qabul atau apa saja yang dikenal dalam adat kebiasaan di masyarakat sebagai serah terima merupakan bentukbentuk yang digunakan hukum untuk menunjukkan kerelaan. ${ }^{6}$

Akad atau kontrak berkaitan dengan barang/harta benda (mâl), hak pemanfaatan harta benda, dan transfer kepemilikan atas barang/hak atas pemanfaatan harta benda dari satu pihak ke pihak lain. Mâl atau harta benda dalam fikih muamalah dibagi dua, yakni: dapat dipindahkan dan tidak dapat dipindahkan, dapat diganti dan tidak dapat diganti, pasti 'ayn dan tidak pasti (dayn). 'Ayn berupa aset riil sedangkan dayn berupa aset keuangan, seperti uang, emas, valuta asing, saham, sukuk. ${ }^{7}$

Kepemilikan harta dapat dibedakan tiga, yaitu: ${ }^{8}$ kepemilikan aset (milk al-'ayn), kepemilikan utang (milk al-dayn) serta kepemilikan hak pemanfaatan atas barang (milk al-manfa'at). Apabila seseorang mendapatkan kepemilikan atas 'ayn (aset riil), maka ia juga mendapat kepemilikan atas manfa'at. Milk al-'ayn bersifat pasti dan tidak terkait waktu, yang berarti jika seseorang mendapat kepemilikan atas aset melalui pembelian, asetnya tersebut tunduk pada kebijaksanaannya. Kepemilikan tidak dapat diakhiri atau dihilangkan, tetapi dapat dialihkan atas keinginannya dan sesuai dengan kontrak (akad) sah yang sesuai dengan peraturan hukum yang relevan.

Penetapan akad dalam keuangan syariah sangat penting, khususnya dalam penerbitan sukuk di Pasar Modal karena pelaksanaannya harus sesuai dengan prinsip Syariah. Oleh sebab itu, konsep akad dalam perspektif fikih dan bagaimana implementasi penggunaan akad dalam menerbitkan sukuk harus jelas terutama berkaitan dengan pemidahan kepemilikan antara penerbit sukuk dengan investor apakah terjadi pemindahan kepemilikan aset, kepemilikan hutang atau kepemilikan

${ }^{6}$ M. Quraish Shihab, Tafsir Al-Mishbah: Pesan, Kesan, dan Keserasian Al-Qur'an (Ciputat: Lentera Hati, 2000), h. 413.

${ }^{7}$ Muhammad Ayub, Understanding Islamic Finance: A-Z Keuangan Syariah (PT Gramedia Pustaka Utama, 2007), h. 159.

${ }^{8}$ Faozi dan Rahmiyanti, Al-Mustashfa: Jurnal Penelitian Hukum Ekonomi Syariah, 4.1 (2016). 
manfaat atas suatu barang. Dalam konsep fikih terdapat banyak jenis akad yang dapat digunakan dalam keuangan syariah baik pada pasar uang syariah maupun pada pasar modal syariah.

Namun tidak semua akad syariah dapat diterapkan pada pasar modal syariah karena produk yang ditawarkan lebih sedikit, berbeda penerapan pada perbankan syariah dengan produk yang lebih banyak dan bervariasi jenisnya.

\section{Jenis Akad dalam Pasar Modal Syariah}

Pada bulan Mei 2003, Accounting and Auditing Organization for Islamic Institutions (AAOIFI) ditetapkan 14 sukuk yang dapat diterbitkan sesuai dengan standard syariah. ${ }^{9}$ Sukuk yang sesuai dengan standard AAOIFI adalah Sukuk Mudhârabah, Sukuk Musyârakah, Sukuk Ijârah, Sukuk Murâbahah, Sukuk Salam, dan Sukuk Istishnâ. Selain enam akad tersebut, terdapat dua akad penerbitan sukuk yang dipraktikkan pada penerbitan sukuk di Malaysia, yakni akad bay al-inah dan akad bay aldayn.

Penjelasan kedelapan akad tersebut ditinjau dari perspektif fikih sebagai berikut:

\section{Akad Murâbahah}

Murâbahah berasal dari kata Ribh, yang berarti perolehan, keuntungan, atau tambahan. ${ }^{10}$ Pelaksanaan jual beli dengan akad murâbahah, penjual harus mengungkapkan biayanya pada saat akad terjadi serta penetapan marjin keuntungan yang disetujui. Bay' al-murâbahah adalah menjual barang dengan harga yang ditetapkan dipasaran dengan tambahan keuntungan yang diketahui. ${ }^{11}$

${ }^{9}$ Eka Nuraini Rachmawati \& Ab Mumin bin Ab Ghani, 'Akad Jual Beli dalam Perspektif Fikih dan Praktiknya di Pasar Modal Indonesia', Al-'Adalah, 12.2 (2015), 785-806 <https://doi. org/10.24042/adalah.v12i2.214>.

${ }^{10}$ Ayub, Understanding Islamic Finance: A-Z Keuangan Syariah, h. 337.

${ }^{11}$ Abdul Rashid Khairuddin, Kobayashi Kiyoshi, and Hasan Sharina Farihah, Concept And Application Of Shariah For The Construction Industry: Shariah Compliance In Construction Contracts, Project Finance And Risk Management (World Scientific, 2018). 
Jual beli murâbahah dipraktikkan pada zaman sebelum Islam yang terdapat dalam al-Muwatta' kitab pertama Imam Malik yang mencatat berbagai hadis Nabi Muhammad Saw. Menurut Imam Malik, murâbahah dilakukan dan diselesaikan dengan pertukaran barang dengan harga, termasuk marjin keuntungan yang telah disetujui bersama pada saat itu dan pada tempat itu. Jadi jual beli tidak dilakukan secara kredit. Namun Imam Syafii dalam kitab al-Umm memperluas konsep pelaksanaan murâbahah secara kredit. ${ }^{12}$

Al-Marghinani, fukaha Hanafi, mendefinisikan murâbahah sebagai penjualan barang apa pun pada harga pembelian yang ditambah dengan jumlah yang tetap sebagai keuntungan. ${ }^{13}$ Dengan demikian maka akad murâbahah merupakan akad jual beli yang pada harga asal dengan tambahan keuntungan yang disepakati. Akadnya menjadi sah apabila pembeli mengetahui harga awal, biaya tambahan jika ada, dan jumlah keuntungannya. ${ }^{14}$

Oleh sebab itu, murâbahah adalah kontrak yang berdasarkan kepercayaan atau kontrak buŷu al-amânah Dinamakan jual-beli amanah, karena ia bergantung kepada kepercayaan penjual kepada harga barang yang dijual di pasar yang diberitahu oleh pembeli. ${ }^{15}$ Jika pembayaran dilakukan secara tangguh yang harganya dibayar secara angsuran dalam tempo waktu yang disepakati, jual beli ini disebut bay' bithaman alajil (BBA) atau bay' mu'ajjal. Ajil memiliki makna jangka waktu yang ditetapkan untuk melunasi hutang.Angsuran di dalam bahasa Arab dikenal

${ }^{12}$ Terkait artikel yang membahas murâbahah bisa dilihat karya Asmi Nur Siwi Kusmiyati. "Risiko Akad dalam Pembiayaan Murabahah pada BMT di Yogyakarta (dari Teori ke Terapan)." La_ Riba 1, no. 1 (2007): h. 27-41. Bagya Agung Prabowo. "Konsep Akad Murabahah Pada Perbankan Syariah (Analisa Kritis Terhadap Aplikasi Konsep Akad Murabahah di Indonesia dan Malaysia)." Jurnal Hukum IUS QUIA IUSTUM 16, no. 1 (2009): 106-126. Fanny Yunita Sri Rejeki. "Akad Pembiayaan Murabahah dan Praktiknya Pada PT Bank Syariah Mandiri Cabang Manado." Lex Privatum 1, no. 2 (2013). Atik Emilia Sula. "Reformulasi Akad Pembiayaan Murabahah dengan Sistem Musyarakah Sebagai Inovasi Produk Perbankan Syariah.” Makalah Disampaikan pada Simposium Nasional Akuntansi XII di Universitas Jendral Soedirman, Purwokerto (2010). Nurul Qomariyah, dan Iwan Triyuwono. "Penentuan Margin Akad Murabahah pada Bank Muamalat Indonesia Cabang Malang." Jurnal Ilmiah Mahasiswa FEB 2, no. 2 (2013).

${ }^{13}$ Ayub, Understanding Islamic Finance: A-Z Keuangan Syariah, h. 337.

${ }^{14}$ Ayub, Understanding Islamic Finance: A-Z Keuangan Syariah, h. 338.

${ }^{15}$ Ab Mumin Ab Ghani, Sistem Kewangan Islam dan Pelaksanaannya di Malaysia (Jabatan Pengajian Islam, Fakulti Sastera dan Sains Sosial, Universiti Malaya, 1997), h. 413. 
dengan istilah al-taqsît yaitu pembagian hutang kepada beberapa bagian tertentu, yang dilunasi pada masa-masa tertentu ${ }^{16}$ Oleh sebab itu, bay' bithaman al-ajil disebut juga sebagai bay' al-taqsit.

Dalam kontrak jual beli bay' bithaman ajil, jika harga naik, pembeli mendapatkan keuntungan karena membeli barang tersebut berbasiskan pembayaran ditunda dengan harga yang lebih murah, jika harga turun, penjual mendapatkan keuntungan karena berhasil menjual barang yang dibelinya dengan berbasiskan pembayaran tangguh dengan harga yang lebih tinggi. Jadi dalam kontrak bay' bithaman ajil, sesuai dengan konsep al-ghunm bil al-ghurm, yakni keuntungan beriringan dengan risiko. Dengan syarat jual-beli harus diselesaikan pada satu harga sehingga kewajiban diketahui oleh semua pihak. ${ }^{17}$

\section{Akad Istishnâ'}

Secara bahasa, istisnẩ berasal dari akar kata sana’a (صنع) ditambah alif, sin, dan ta' menjadi istisnâ' (استصناع) yang dapat diartikan talabalsun'ah (طلب الصنعة) meminta dibuatkan barang atau "meminta untuk dibuatkan sesuatu"18 Pengertian istisnầ menurut istilah, didefinisikan sebagai akad meminta seseorang untuk membuat sebuah barang tertentu dalam bentuk tertentu. ${ }^{19}$

Pengertian istisnâ' merupakan akad yang dilakukan dengan seseorang untuk membuat barang tertentu dalam tanggungan dan akad tersebut merupakan akad membeli sesuatu yang akan dibuat oleh seseorang. Menurut ahli fikih, pengertian istisnầ adalah suatu permintaan untuk mengerjakan sesuatu yang tertentu menurut cara tertentu yang materinya (bahan bakunya) dari pihak pembuat (tukang). ${ }^{20}$

Menurut jumhur ulama, hukum transaksi istisnẩ hukumnya boleh, begitu pula pendapat ahli fikih Hanâfiyah, jual beli istisnâ diperbolehkan karena telah lama menjadi kebiasaan ('urf) yang mengandung unsur

\footnotetext{
${ }^{16}$ Khairuddin, Kiyoshi, dan Farihah, Concept And Application Of Shariah, h. 131.

${ }^{17}$ Khairuddin, Kiyoshi, dan Farihah, Concept And Application Of Shariah, h. 112.

${ }^{18}$ Ahmad Wardi Muslich, 'Figh Muamalat, Cet. Ke-1', (Jakarta: Amzah, 2010), h. 252.

${ }^{19}$ Wahbah Az-Zuhaili, 'Figh Islam Wa Adillatubu, Jilid 10', (Jakarta: Gema Insani, 2011), h. 268.

${ }^{20}$ Muslich, Figh Muamalat, h. 253.
} 
kebaikan (istihsân). Jadi hikmah dibolehkannya jual beli istisnầ karena keberadaannya telah menjadi keperluan manusia. ${ }^{21}$

\section{Akad Salam}

Akad salam disyaratkan berdasarkan dalil dari Alquran, sunnah dan ijmak ulama. Akad salam atau salaf adalah penjualan sesuatu dimasa yang akan datang dengan imbalan sesuatu yang sekarang, atau menjual sesuatu yang dijelaskan sifatnya dalam tanggungan. Para ulama Syâfi'iyyah dan Hanâbilah mendefinisikan akad salam sebagai akad atas sesuatu yang disebutkan dalam sifatnya dalam perjanjian dengan penyerahan tempo dengan imbalan harga yang diserahkan dalam majelis akad. ${ }^{22}$

Pengertian salaf atau istalafa sama dengan iqtarada yang artinya "berutang". Menurut istilah, mazhab Hanafi mendifinisikan salam sebagai jual beli tempo dengan tunai. Menurut Mazhab Maliki, salam adalah akad jual beli dimana modal (harga) dibayar di muka, sedangkan barang diserahkan di belakang. Jadi salam adalah salah satu bentuk jual beli di mana uang harga barang dibayarkan secara tunai, sedangkan barang yang dibeli belum ada, hanya sifat-sifat, jenis, dan ukurannya sudah disebutkan pada waktu perjanjian dibuat. ${ }^{23}$

\section{Akad Bay al-Inah}

Kata 'al-inah" berasal dari bahasa Arab yang berarti "tunai" atau "segera". Tetapi, yang dimaksud dengan bay al-'inah adalah menjual harta

${ }^{21}$ Eka Nuraini Rachmawati \& Ab Mumin bin Ab Ghani. Terkait artikel yang membahas istisnâ' bisa dilihat pada Muhammad Al-Bashir Muhammad Al-Amine. "Istisna and Its Application In Islamic Banking." Arab Law Quarterly 22 (2001): h. 22-48.

${ }^{22}$ Az-Zuhaili, Fiqh Islam Wa Adillatuhu, h. 242.

${ }^{23}$ Muslich, h. 243. Terkait artikel tentang salam bisa dilihat pada karya Anas Affandi. "Makna Pembiayaan Salam Perspektif Perbankan Syariah dan Petani di Probolingo." Jurnal Ilmiah Mahasiswa FEB 2, no. 2 (2013). Ahmad Roziq, Nur Hisamuddin, Nining Ika Wahyuni, dan Indah Purnamawati. "Model Pembiayaan Salam pada Petani Singkong dan Usaha Kecil Berbahan Singkong di Kabupaten Jember." Jurnal Akuntansi Universitas Jember 12, no. 2 (2014). Siti Mujiatun. "Jual Beli dalam Perspektif Islam: Salam dan Istisna'" JRAB: Jurnal Riset Akuntansi \& Bisnis 13, no. 2 (2014). Muhammad Akhyar Adnan. "Faktor-Faktor yang Mempengaruhi Belum Diaplikasikannya Akad Salam pada Perbankan Syariah (Studi pada 3 BPRS Yogyakarta) dan Kaitannya dengan Pengurangan Tingkat Kemiskinan.” International Conference On Islamic Economics And Financial Inclution (ICIEFI) UMY, 2015. 
dengan bayaran angsuran, kemudian segera membelinya kembali dengan bayaran tunai. Menurut al-Bahuty, bay' al-inah adalah penjualan barang kepada seseorang dengan harga kredit dan barang diserahkan kepada pembeli, kemudian dibeli kembali oleh penjual sebelum mengambil bayarannya dengan uang tunai lebih kecil dari harga asalnya. ${ }^{24}$

Menurut al-Jauhari kata “inah” bermakna pinjaman dan utang. Al-Jauhari mengatakan bahwa 'inah' adalah jika ada seorang pedagang menjual barang secara kredit, kemudian dia membelinya kembali dengan harga yang lebih rendah. Jual beli secara inah berarti seseorang menjual barang kepada orang lain dengan pembayaran diangsur, lalu barang itu diserahkan kepada pembeli, kemudian penjual itu, membeli kembali barangnya sebelum uangnya lunas dengan harga lebih rendah dari harga pertama. $^{25}$

Pendapat ulama berbeda tentang bay' al-inah, Abû Hanifah mengatakan hukumnya fâsid, sedangkan Imam Malik dan Hanbali mengatakan akadnya batal. Abû Yusuf berpendapat bahwa bay' al-inah hukumnya makruh, sedangkan pandangan para sahabat seperti Aisyah dan Ibn Abbas dan dari tabi'in Ibn Sirin, al-Sha'bi dan pandangan jumhur ulama hukum bay'al-inah haram. Mayoritas ulama fikih selain Imam Syâfi'i menyatakan bahwa jual beli ini adalah rusak (fâsid) dan tidak sah. Karena, jual beli ini menjadi sarana munculnya riba dan menyebabkan terjadinya sesuatu yang dilarang oleh Allah sehingga jual beli ini tidak sah. ${ }^{26}$ Namun mazhab Imam Syâfi'i membolehkan penggunaan kontrak bay' al-inah karena akad jual beli yang dilakukan telah memenuhi rukun yaitu ijab dan qobul, tanpa memandang kepada niat pelaku. ${ }^{27}$

${ }^{24}$ Nazaruddin Abdul Wahid, Sukuk: Memahami \& Membedah Obligasi Pada Perbankan Syariah (Ar-Ruzz Media, 2010), h. 57.

${ }^{25}$ Abdurrahman Sa'di, Fiqih Jual Beli: Panduan Praktis Bisnis Syariah (Senayan Publishing, 2008), h. 135.

${ }^{26}$ Az-Zuhaili, Figh Islam Wa Adillatuhu, h. 135.

${ }^{27}$ Az-Zuhaili, Figh Islam Wa Adillatubu, h. 59. 


\section{Akad Bay' al-Dayn}

Bay' al-Dayn adalah suatu akad jual beli dengan objek jual belinya adalah piutang atau tagihan (dayn).$^{28}$ Bay' al-dayn adalah seseorang yang mempunyai hak mengutip hutang yang akan dibayar pada masa yang akan datang dan dia dapat menjual haknya kepada orang lain dengan harga yang disetujui bersama. ${ }^{29}$

Konsep bay' al-dayn sebenarnya merujuk kepada pembiayaan hutang yaitu peruntukkan sumber keuangan yang diperlukan oleh unit-unit pembiayaan, perdagangan dan jasa dengan cara menjual atau membeli kertas-kertas dan dokumen-dokumen perdagangan. ${ }^{30}$ Bentuk jual beli hutang diklasifikasi menjadi tiga, yaitu: ${ }^{31}$

1) Bentuk jual beli utang oleh pihak kreditur kepada pihak pengutang (debitur) lebih dekat pada kontrak hiwâlah. Jual beli utang seperti ini dibenarkan oleh ulama Hanâfi, karena tidak termasuk ke dalam jual beli gharar. Mazhab Maliki memiliki pendapat yang sama bahwa jual beli utang kepada pihak debitur dibolehkan.

2) Bentuk jual beli utang oleh pihak kreditur kepada pihak ketiga dengan harga tunai. Penjualan utang semacam ini tidak dibenarkan oleh Mazhab Hanafi dan Hanbali, karena penjual utang tidak berkemampuan untuk menyerahkan utang tersebut pada waktunya. Mazhab Maliki membenarkan jual beli hutang kepada pihak ketiga dengan persyaratan tertentu.

3) Penjualan utang kepada pihak pengutang atau pihak ketiga tetapi dengan cara pembayaran tertangguh. Menurut Ibn Taimiyah jual beli utang seperti ini tidak dibenarkan dan golongan ulama terdahulu menamakan bay' alkali bi al-kali yakni akad jual beli hutang dengan hutang.

\section{Akad Musyârakah}

Pengertian syirkah (musyârakah) secara harfiah berarti percampuran. Menurut bahasa, syirkah adalah bercampurnya suatu harta dengan harta yang lain sehingga keduanya tidak dapat dibedakan. Menurut ulama

\footnotetext{
${ }^{28}$ Ahmad Ifham Sholihin, Buku Pintar Ekonomi Syariah (Gramedia Pustaka Utama, 2013),
} h. 139.

${ }^{29}$ Ab Mumin Ab Ghani, Sistem Kewangan Islam dan Pelaksanaannya di Malaysia.

${ }^{30}$ Ab Mumin Ab Ghani, Sistem Kewangan Islam dan Pelaksanaannya di Malaysia, h. 280.

${ }^{31}$ Wahid, Sukuk: Memahami \& Membedah Obligasi Pada Perbankan Syariah, h. 51-55. 
Syâfi'iyyah, syirkah adalah tetapnya hak kepemilikan bagi dua atau lebih sehingga tidak terbedakan antara hak pihak yang satu dengan hak pihak yang lain. Menurut ulama Hanafiyah, syirkah adalah transaksi antara dua orang yang bersekutu dalam modal dan keuntungan. ${ }^{32}$ Pengertian musyârakah menurut bahasa ialah pencampuran harta di antara dua orang atau lebih. ${ }^{33}$

Menurut Saad Abdul Sattar al-Harran, musyârakah (syirkah) sebagai bentuk perkongsian di mana dua orang atau lebih bergabung baik dalam bentuk modal atau tenaga kerja atau keduanya dalam kadar tertentu bagi masing-masing dengan pembagian keuntungan, kerugian, dan tanggung jawab masing-masing.

Hukum syirkah dibolehkan oleh syariat, berdasarkan Alquran, sunnah dan ijmak. Dalil Alquran, firman AllahQ.s. al-Nisa' [4]: 12 berbunyi:

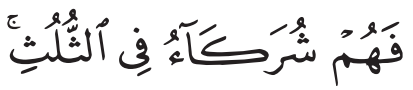

..maka mereka bersekutu dalam bagian yang sepertiga itu.

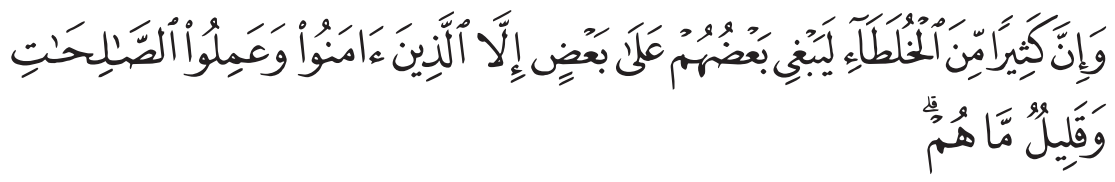

...dan sesungguhnya kebanyakan dari orang-orang yang berserikat itu sebahagian mereka berbuat zalim kepada sebahagian yang lain, kecuali orang-orang yang beriman dan mengerjakan amal yang saleh; dan amat sedikitlah mereka ini.(Q.s. Shâd [38]: 24).

Adapun dalil dari sunnah, hadis qudsi yang diriwayatkan oleh Abû Hurairah secara marfû̀ dari Rasullulah bahwa beliau bersabda, "Sesungguhnya Allah berfirman, "Aku adalah pihak ketiga dari dua orang yang bersekutu, selama salah seorang dari keduanya tidak menghianati yang lain, maka Aku keluar dari persekutuan tersebut.( H.r. Abû Dawud serta Hakim).

Syirkah dikelompokkan menjadi dua, yaitu syirkah amlak (kongsi harta) dan syirkah uqûd (kongsi transaksi). Syirkah amlak atau syirkah

${ }^{32}$ Az-Zuhaili, Figh Islam Wa Adillatuhu, h. 441.

${ }^{33}$ Wahid, Sukuk: Memahami \& Membedah Obligasi Pada Perbankan Syariah, h. 62. 
milk merupakan bentuk persekutuan diantara dua orang atau lebih dalam kepemilikan harta yang diperoleh tanpa disertai akad. Syirkah amlak dikelompokkan menjadi dua, yaitu syirkah ikhtiyâr (sukarela), yaitu syirkah yang lahir atas kehendak dua pihak yang bersekutu. Kedua, syirkah jabar (paksa), yaitu persekutuan yang terjadi diantara dua orang atau lebih tanpa kehendak mereka. Hukum kedua jenis syirkah ini bagaikan pihak asing atas sekutunya yang lain. Sehingga, salah satu pihak tidak berhak melakukan tindakan apapun terhadap harta tersebut tanpa izin dari yang lain, karena masing-masing sekutu tidak memiliki kekuasaan atas bagian saudaranya. ${ }^{34}$ Syirkah 'uqûd adalah bentuk persekutuan diantara dua pihak atau lebih untuk menjalankan suatu usaha berdasarkan prinsip bagi hasil. ${ }^{35}$

\section{Akad Mudhârabah}

Mudhârabah dari segi bahasa berasal dari kata dasar al-darb:ضرب يضرب ضربا ضyang berarti bergerak, menjalankan, memukul, kemudian mendapat tambahan huruf sehingga menjadi ضارب يضارب مضارب yang berarti saling bergerak, saling pergi, atau saling menjalankan atau saling memukul. Dalam arti lain, ضارب berarti berdagang atau memperdagangkan. ${ }^{36}$

Kata daraba dalam Alquran digunakan dalam rangkaian kata ayat "darb fi al-ardi", yang memberi maksud keluar mengembara untuk menjalankan perniagaan atau melakukan perjalanan untuk berniaga. ${ }^{37}$ Penggunaan makna ini adalah bersesuaian dengan Firman Allah dalam Alquran Surah al-Muzammil [73]: 20:

${ }^{34}$ Az-Zuhaili, Fiqh Islam Wa Adillatuhu, h. 443.

${ }^{35}$ Eka Nuraini Rachmawati \& Ab Mumin bin Ab Ghani. Terkait artikel yang membahas syirkah (musyârakah) dapat dilihat pada karya Sirajul Arifin. "Musyârakah: Antara Fikih dan Perbankan Syariah.” MIQOT: Jurnal Ilmu-ilmu Keislaman 36, no. 1 (2016). Mila Fursiana Salma Musfiroh. "Musyârakah dalam Ekonomi Islam (Aplikasi Musyârakah dalam Fiqih dan Perbankan Syariah)." Syariati: Jurnal Studi Al-Qur'an dan Hukum 2, no. 01 (2016): h. 173-185. Wahyu Alifi. "Pelaksanaan Akad Musyârakah Mutanâqishah dalam Pembiayaan Perumahan pada Bank Muamalat Cabang Malang." PhD diss., Universitas Islam Negeri Maulana Malik Ibrahim, 2012. Agus Arwani. "Studi Kritis Akad Pembiayaan Musyârakah pada Perbankan Syari'ah." Jurnal Hukum Islam (2016).

36 Sohari Sahrani, 'Ru'fah Abdullah', Fikih Muamalah, 2011, h. 172-173 (187).

${ }^{37}$ As-Sayyid Sabiq dkk, Fiqh Al-Sunnah, (Dâr al-Rayyân lil-Turâth, 1990), h. 173. 


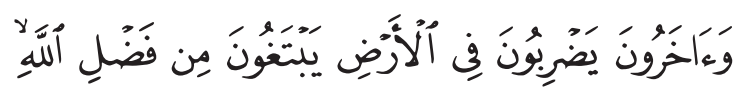

...dan orang-orang yang berjalan di muka bumi mencari sebagian karunia Allah... (Q.s. al-Muzammil [73]: 20).

Istilah mudhârabah dengan pengertian berpergian untuk berdagang digunakan oleh penduduk Irak. Sedangkan penduduk Hijaz menggunakan istilah qirad, yang diambil dari kata qard (قرض) yang artinya al-qat’u (القطع) yakni memotong. Dinamakan demikian, karena pemilik modal memotong sebagian hartanya untuk diperdagangkan oleh 'amil dan memperoleh keuntungannya. Praktik seperti ini dikenal sebagai "al-muqâradab" yang berarti sama rata karena masing-masing berkongsi modal dan akan turut sama mendapatkan keuntungan dari sesuatu perniagaan yang dijalankan." ${ }^{38}$

Mudhârabah adalah akad yang berlaku antara dua pihak dengan syarat salah seorang dari keduanya menyerahkan sejumlah uang kepada pihak yang lain untuk didagangkan dan keuntungan yang diperoleh dibagi dua sesuai dengan kesepakatan. ${ }^{39}$ Hadis Rasul yang dapat dijadikan rujukan dasar akad transaksi mudhârabah adalah:

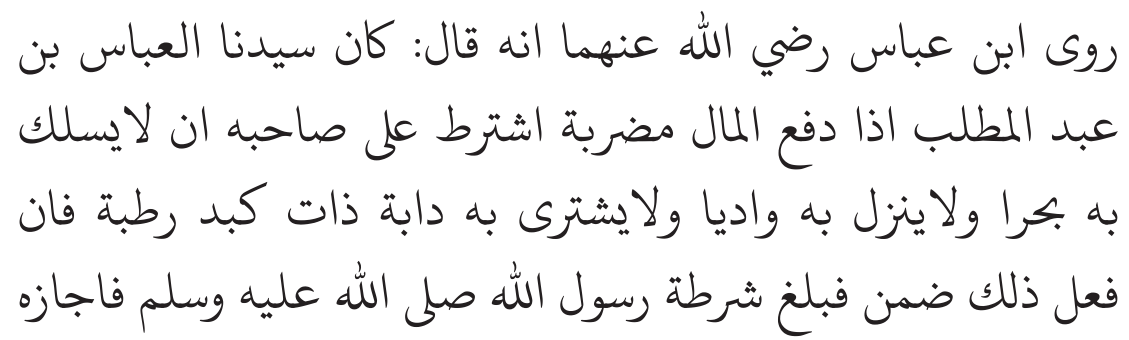

Diriwayatkan oleh ibnu Abbas bahwasannya Sayyidina Abbas jikalau memberikan dana ke mitra usahanya secara mudhârabah, ia mensyaratkan agar dananya tidak dibawa mengarungi lautan, menuruni lembah yang berbahaya, atau membeli ternak yang berparu-paru basah, jika menyalahi peraturan maka yang bersangkutan bertanggung jawab atas dana tersebut. Disampaikannyalah syarat-syarat tersebut kepada Rasulullah Saw. Dan Rasulullah pun membolehkannya. (H.r. al-Baihaqi 6: 111)

${ }^{38}$ Mustafa Al-Khin, Mustada al-Bugha, and Ali al-Sharbaji, Al-Fiqh Al-Manhaji: Ala Mazhab Al-Imam Al-Syafii (Dar al-Syamiah, 1996), h. 371.

39 Sabiq dkk, Fiqh Al-Sunnah, h. 173. 
Dari Suhaib RA bahwa Nabi Muhammad Saw. bersabda:

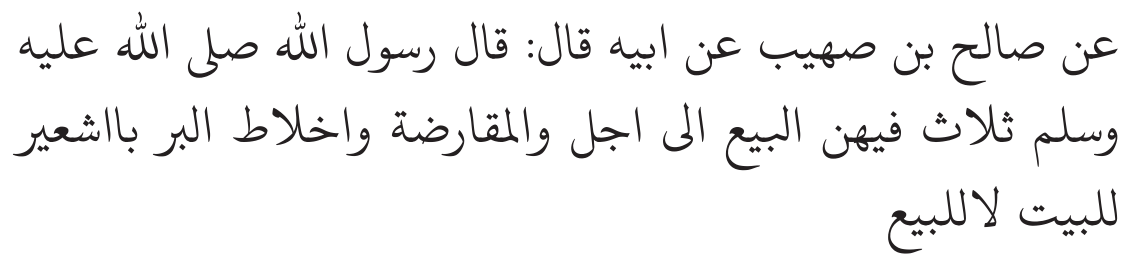

Dari Shahih bin Shuhaib r.a. bahwa Rasulullah saw. Bersabda, "Tiga hal yang di dalamnya terdapat keberkatan: jual beli secara tangguh, muqaradhah (mudharabah), dan mencampur gandum dengan tepung untuk keperluan rumah, bukan untuk dijual." (H.r. Ibnu Majah: 2289)

Praktik akad mudhârabah dalam transaksi keuangan Islam menggunakan landasan hukum atas dasar Firman Allah Swt. dalam AlquranQ.s. al-Muzammil [73]: 20 dan Q.s. al-Jumu'ah [62]:10 yang berbunyi:

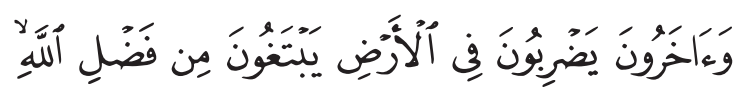

Dan orang-orang yang berjalan di muka bumi mencari sebagian karunia Allah.... (Q.s. al-Muzammil [73]: 20)

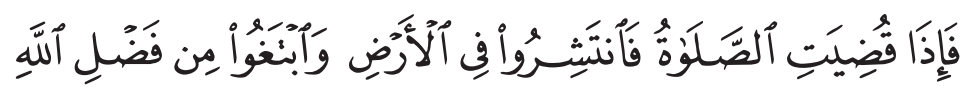

Apabila shalat telah dilaksanakan, maka bertebaranlah kamu di muka bumi, dan carilah karunia Allah. (Q.s. al-Jumu'ah [62]: 10)

Dalil mudhârabah dalam hadis Rasulullah Saw.berbunyi:

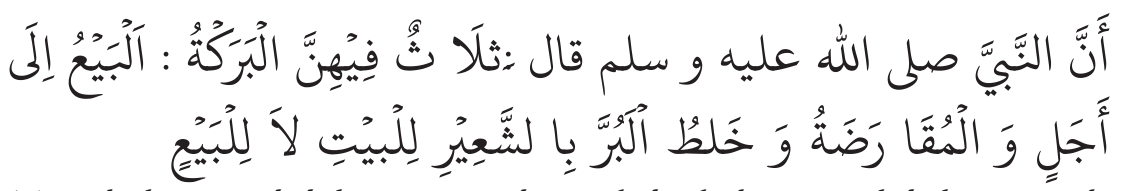

Tiga hal yang didalamnya terdapat keberkahan: jual beli tangguh, muqâradah (mudhârabah), dan mencampur gandum dengan tepung untuk keperluan bukan untuk keperluan rumah, bukan untuk dijual". (H.r. Ibnu Majah).

Menurut Wahbah Zuhaili, mudhârabah didefinisikan sebagai akad yang didalamnya pemilik modal memberikan (harta) pada 'amil (pengelola) untuk mengelolanya, dan keuntungannya menjadi milik bersama sesuai dengan apa yang mereka kesepakatan, sedangkan kerugiannya hanya 
menjadi tanggungan pemilik modal saja. ${ }^{40}$

Sayid Sabiq, memberikan definisi mudhârabah adalah suatu akad antara dua pihak di mana salah satu pihak memberikan uang (modal) kepada pihak lain untuk diperdagangkan dengan ketentuan bahwa keuntungan dibagi diantara mereka berdua sesuai dengan kesepakatan mereka. ${ }^{41}$ Jadi mudhârabah merupakan akad yang dilakukan antara dua pihak yakni pihak pemilik modal dan pengelola untuk melakukan kerjasama aktivitas bisnis di mana keuntungan yang diperoleh akan dibagi dua sesuai dengan kesepakatan.

\section{Akad ljârah}

Sewa-menyewa dalam bahasa Arab dikenal dengan istilah ijârah. Ijârah berasal dari kata "a ja ro (اجر) dan memiliki beberapa sinonim, dapat diartikan menyewakan, memberinya upah dan memberinya pahala. Menurut bahasa, ijârah artinya, sewa menyewa atau jual beli manfaat. ${ }^{42}$ Sayid Sabiq mengemukakan, bahwa al-ijârah berasal dari kata 'al-ajru' (الاجر) yang berarti 'al-iwadh' (sewa atau imbalan, ganjaran atau pahala). Jadi ijârah menurut bahasa dan secara syarak memiliki makna jual beli manfaat. ${ }^{43}$

Terdapat perbedaan pendapat tentang ijârah di kalangan ulama Hanafiah, Malikiyah, Syafi'iyyah dan Hanabilah. ${ }^{44}$ Ulama Hanafiah, mendefinisikan ijârah sebagai akad atas manfaat disertai imbalan berupa harta. Namun ulama Malikiyah dan Hanabilah memberi pengertian bahwa ijârah adalah suatu akad yang memberikan hak kepemilikan manfaat sesuatu yang mubah untuk masa tertentu disertai imbalan. ${ }^{45}$

Menurut ulama Syafi'iyyah, akad ijârah adalah suatu akad atas manfaat yang mengandung maksud yang tertentu, mubah, dan dapat didermakan serta dibolehkan dengan imbalan tertentu. Menurut istilah

\footnotetext{
${ }^{40}$ Az-Zuhaili, Fiqh Islam Wa Adillatuhu, h. 476.

${ }^{41}$ Sabiq dkk, Fiqh Al-Sunnah, h. 173.

${ }^{42}$ Muslich, Fiqh Muamalat, h. 315-316.

${ }^{43}$ Sabiq dkk, Fiqh Al-Sunnah, h. 155.

${ }^{44}$ Muslich, Figh Muamalat, h. 316-317.

${ }^{45}$ Az-Zuhaili, Fiqh Islam Wa Adillatubu, h. 387.
} 
fukaha, ijârah ialah kontrak untuk mendapatkan manfaat (jasa) tertentu yang boleh dibayar dan dihalalkan dengan barang tertentu. Kontrak ini dilaksanakan dengan memindahkan hak milik jasa (manfaat) tersebut. ${ }^{46}$ Akad ijârah (sewa) akad untuk memperoleh manfaat dengan disertai bayaran. Dengan kata lain, ijarah merupakan bentuk jual beli manfaat, untuk mendapatkan imbalan.

Praktik akad ijârah dalam transasaksi keuangan Islam menggunakan landasan hukum sama ada dari Alquran dan Hadis Nabi. Hal ini merujuk kepada pendapat mayoritas ulama memperbolehkan akad ijârah dengan dalil Alquran, sunnah, dan ijmak sebagai berikut. Kemudian akad ijarah tersebut, digunakan dalam penerbitan Sukuk Ijârah Ijarah di Pasar Modal Indonesia, berdasarkan pendapat peserta Rapat Pleno Dewan Syari'ah Nasional pada hari Kamis, tanggal 8 Muharram 1412 H/13 April 2000. Landasan hukum akad ijarah berdasarkan Alquran:

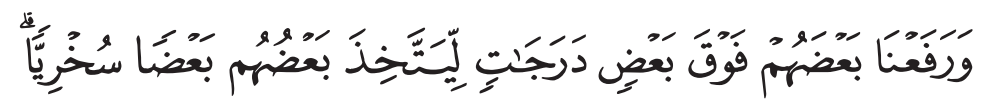

Dan Kami telah meninggikan sebahagian mereka atas sebagian yang lain beberapa derajat, agar sebagian mereka dapat mempergunakan sebagian yang lain. (Q.s. al-Zukhruf [43]: 32).

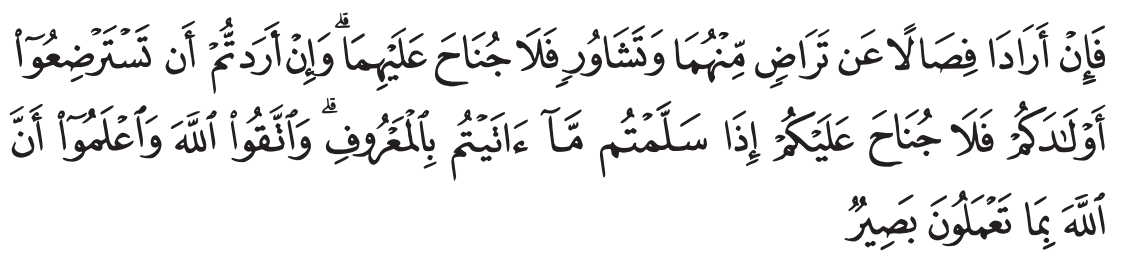

Dan jika kamu ingin anakmu disusukan oleh orang lain, maka tidak ada dosa bagimu apabila kamu memberikan pembayaran menurut yang patut. Bertakwalah kamu kepada Allah dan ketahuilah bahwa Allah maha melihat apa yang kamu kerjakan. (Q.s. al-Baqarah [2]: 233).

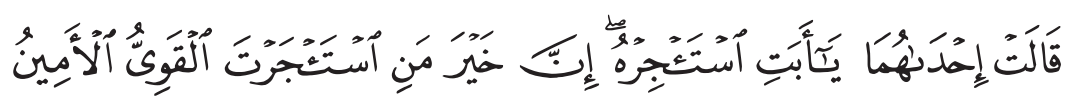

Salah seorang dari kedua wanita itu berkata: "Ya bapakku ambillah ia sebagai orang yang bekerja (pada kita), karena Sesungguhnya orang

${ }^{46}$ Az-Zuhaili, Fiqh Islam Wa Adillatuhu, h. 389. 
yang paling baik yang kamu ambil untuk bekerja (pada kita) ialah orang yang kuat lagi dapat dipercaya". (Q.s. al-Qasas [28]: 26).

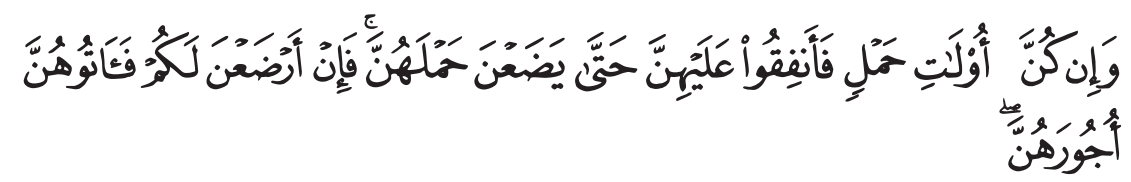

Dan jika mereka (istri-istri yang sudah ditalak) itu sedang hamil, maka berikanlah kepada mereka nafkahnya hingga mereka bersalin, kemudian jika mereka menyusukan (anak-anak)mu untukmu maka berikanlah kepada mereka upahnya.(Q.s. al-Talaq [65]: 6).

Selain itu, landasan hukum akad ijârah yang tercantum dalam Fatwa Dewan Syariah Nasional No. 72 /MUI/VI/2008 tentang SBSN Ijarah Sale and Lease Back. Hadis riwayat 'Abd ar-Razzaq dari Abu Hurairah dan Abu Sa’id al-Khudri, Nabi Saw. bersabda:

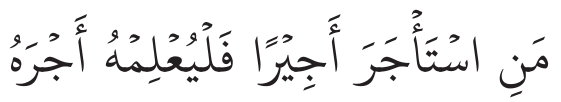

Barang siapa mempekerjakan pekerja, beritahukanlah upahnya. (H.r. Abd ar-Razzaq)

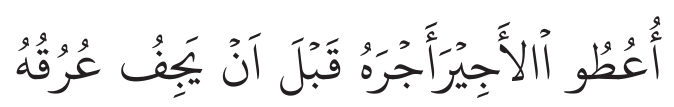

Berikanlah olehmu upah orang sewaan sebelum keringatnya kering. (H.r. Ibnu Majah).

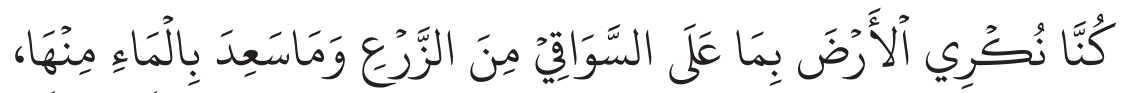

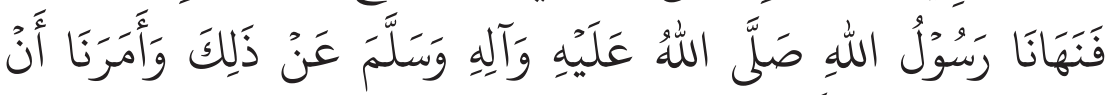

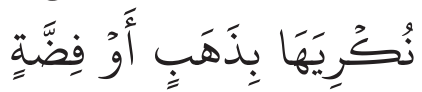

Kami pernah menyewakan tanah dengan (bayaran) hasil pertaniannya maka Rasulullah melarang kami melakukan hal tersebut dan memerintahkan agar kami menyewakannya dengan emas atau perak. (H.r. Ahmad dan Abu Daud)

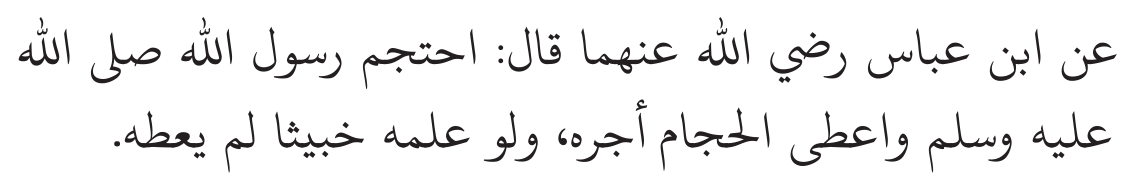


Dari Abbas radhiyallahu 'anhuma, beliau berkata: Rasulullah shallallahu 'alaihi wa sallam pernah berbekam dan memberikan upah tukang bekam itu, dan sekiranya upah profesi bekam itu buruk maka niscaya beliau tidak akan memberikannya. (H.r. Bukhari dan Abu Daud)

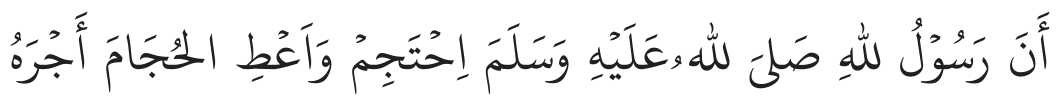

Bahwa Rasululah Saw. bersabda: "Berbekamlah kamu, kemudian berikanlah olehmu upahnya kepada tukang bekam itu." (H.r. Bukhari dan Muslim)

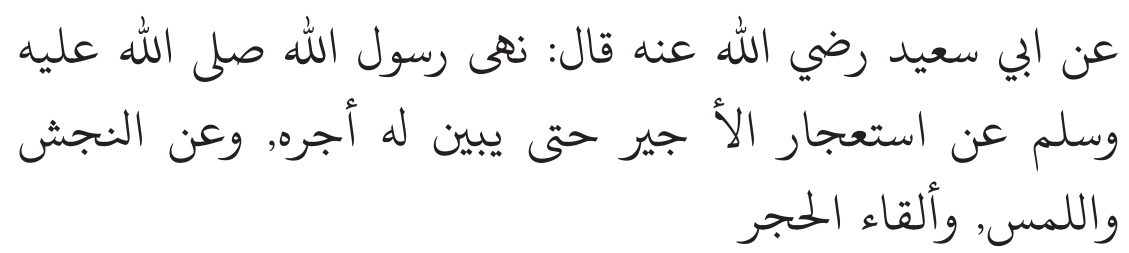

Dari Abu Said radhiyallahu 'anhu, ia berkata: Rasulullah shallallahu 'alaibi wa sallam melarang untuk mengangkat seorang pekerja sampai upahnya dijelaskan terlebih dahulu, beliau juga melarang jual beli dengan cara al-Najasy, al-Lams, dan dengan cara melempar batu. (H.r. Ibnu Majah) Kaidah fikih:

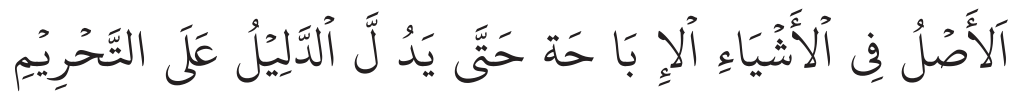

Pada dasarnya, semua bentuk muamalah boleh dilakukan kecuali ada dalil yang mengharamkannya." "47

Ijârah menurut istilah bahasa Arab merujuk kepada upah yang diberikan kepada orang yang melakukan suatu pekerjaan sebagai ganjaran kepada apa yang dilakukannya. Ganjaran tersebut disebut sebagai ajr atau ujrah. Kata 'ajjarahu' atau 'aajarahu' bermakna memberi upah karena kerja yang dilakukan. Perkataan ini hanya digunakan bagi merujuk kepada sesuatu yang memberikan keuntungan dan tidak digunakan untuk sesuatu yang merugikan. Ajr biasanya digunakan untuk merujuk ganjaran akhirat, sementara ujrah pula merujuk kepada ganjaran dunia. ${ }^{48}$

${ }^{47}$ Muslich, Fiqh Muamalat, h. 318.

${ }^{48}$ Muhammad Jawad Mughniyah, Fiqih Lima Mazhab: Ja'fari, Hanafi, Maliki, Syafi'i, Hambali. (Shaf, 2015), h. 483. 
Rukun ijârah menurut Hanâfiyah adalah ijab dan qobul, yaitu dengan lafaz ijârah. Sedangkan rukun ijârah menurut mayoritas ulama ada empat, yaitu dua pelaku akad (pemilik sewa dan penyewa), sîghah (ijab dan qabul), upah, dan manfaat barang.

Objek ijârah terbagi empat: ${ }^{49}$

1. Ijârah terhadap manfaat dari barang, disebut juga ijârah 'ala almanâfi atau ijârah al-a’yan. Contohnya seperti menyewakan gedung, rumah, kapal, mobil dan lainnya.

2. Ijârah terhadap manfaat dari pekerjaan manusia (ijârah'ala al-ảmâl). Seperti mengupah seorang manajer untuk mengelola perusahaan, dan tukang angkat untuk memindahkan barang.

3. Ijârah terhadap perpaduan manfaat manusia dan barang (ijârah 'ala al-manâfi wa al-ämâl). Seperti mengupah seorang atau lembaga membangun rumah sedang alat-alat berasal dari pekerja atau lembaga tersebut; atau mengendarai angkutan umum dimana upah diberikan untuk sopir dan mobil atau kendaraan beratnya.

4. Bila dimasukkan pendapat Ibnu Qayim, maka terdapat obyek ijârah keempat, yaitu ijârah bukan tehadap manfaat, tapi terhadap "barang"'ain, yaitu hasil berkelanjutan dari suatu barang asal, namun zat barang tersebut tetap ada, seperti buah sebagai hasil dari penyewaan pohon.

Beberapa pendapat tersebut, ijârah merupakan akad sewa menyewa atau jual beli manfaat antara dua pihak yaitu antara penyewa dan yang menyewakan barang, yang memberikan hak kepemilikan manfaat dari barang, manfaat dari pekerjaan manusia, perpaduan manfaat dari barang dan dari pekerjaan manusia untuk jangka waktu tertentu dan menerima imbalan.

\section{Akad Jual Beli (Bay’) Sebagai Landasan Penerbitan Sukuk Negara}

Akad jual beli selain diterapkan sebagai landasan penerbitan sukuk korporasi seperti akad salam, istishnâ dan murâbahah juga diterapkan sebagai landasan penerbitan sukuk negara, yang dikenal dengan sebutan

${ }^{49}$ Fathurraman Djamil dkk, 'Aplikasi Pasar Sukuk dalam Perspektif Syariah (Studi Analisis Kesesuaian Syariah Terhadap Aplikasi Pasar Sukuk Domestik dan Global)', 2012, h. 156. 
Sertifikat Berharga Syariah Negara (SBSN). Sukuk Negara diterbitkan dengan menggunakan akad bay' wafa' dikombinasi dengan akad ijârah yang dikenal dengan istilah bay' istighlâl.

\section{Bay Wafa'}

Bay' al-wafa' adalah salah satu bentuk transaksi (akad) yang muncul di Asia Tengah (Bukhârâ dan Balkh) pada pertengahan abad ke 5 Hijriyah dan merambat ke Timur Tengah, dengan tujuan menghindari terjadinya riba dalam pinjam meminjam.

Pada masa itu banyak diantara orang kaya tidak mau meminjamkan uangnya tanpa ada imbalan yang mereka terima. Sementara banyak juga para peminjam uang tidak mampu melunasi uangnya akibat imbalan yang harus mereka bayarkan bersamaan dengan sejumlah uang yang mereka pinjam. Menurut para fukaha imbalan yang diberikan atas dasar pinjam meminjam uang ini termasuk riba. ${ }^{50}$

Akad bay' al-wafa' adalah akad jual beli, maka pembeli dapat dengan bebas memanfaat barang yang dibeli tersebut. Hanya saja pembeli tidak boleh menjual barang tersebut kepada orang lain selain kepada penjual. Menurut ulama jual beli ini dibolehkan, karena tujuannyan untuk menghindari riba. ${ }^{51}$ Definisi lain, bay' wafa' adalah jual beli yang meletakkan syarat bahwa apabila penjual membayar kembali harga barang yang dijual maka pembeli akan mengembalikan barang yang dijual kepada penjual.

Menurut Ibnul 'Abidin, adalah suatu akad di mana seorang yang memerlukan uang menjual barang kepada seseorang yang memiliki uang kas. Barang yang dijual tersebut tidak dapat dipindah-pindah dengan kesepakatan, jika ia dapat mengembalikan harga barang tersebut maka ia dapat meminta kembali barang itu. ${ }^{52}$

Musthafa Ahmad al-Zarqa mengemukakan bahwa barang yang diperjual belikan dalam bay' al-wafa, adalah barang tidak bergerak, seperti

\footnotetext{
${ }^{50}$ Nasrun Haroen dan Fiqh Muamalah, Gaya Media Pratama, (Jakarta, 2007), h. 152.

${ }^{51}$ Haroen dan Muamalah, Gaya Media Pratama, h. 153.

${ }^{52}$ Sabiq dkk, Fiqh Al-Sunnah, h. 155.
} 
tanah perkebunan, rumah, tanah perumahan, dan sawah. ${ }^{53}$ Sementara itu, ulama Hanafiyah menganggap bay' al-wafa' adalah sah dan tidak termasuk ke dalam larangan Rasulullah Saw. yang melarang jual beli yang diikuti syarat, karena sekalipun disyaratkan bahwa harta itu harus dikembalikan kepada pemilik awal, namun pengembalian itu pun harus melalui akad jual beli. ${ }^{54}$

Mekanisme akad bay' al-wafa' terdiri atas tiga tahapan. Pertama, ketika dilakukan transaksi, akad ini merupakan jual beli, karena didalam akad dijelaskan bahawa transaksi itu adalah jual beli, melalui ucapan penjual "saya menjual sawah saya kepada engkau seharga Rm 1000 selama dua tahun". Kedua, setelah transaksi dilaksanakan dan harta beralih ke tangan pembeli, transaksi ini berbentuk ijârah (pinjam meminjam/sewa menyewa), karena barang yang dijual itu harus dikembalikan kepada penjual, sekalipun pemegang harta itu berhak memanfaatkan dan menikmati hasil barang itu selama waktu yang disepakati.Ketiga, diakhir akad, ketika waktu yang disepakati berakhir, bay' al-wafaìni sama dengan al-rahn, karena dengan jatuh tempo yang telah disepakati kedua pihak, penjual harus mengembalikan barang yang dibeli itu kepada penjual secara utuh. ${ }^{55}$

Jadi bay' al-wafa' merupakan gabungan antara akad jual beli dengan akad gadai yang pada awalnya dipraktikkan untuk menghindari riba dan sebagaian besar ulama membolehkannya dengan syarat barang yang dijual berupa harta tidak bergerak seperti tanah, bangunan, rumah dan lainnya.

\section{Bay Istighlâl}

Bay' istighlâl sebenarnya hampir sama dengan jual beli al-wafa, namun pada jual beli istighlâl benda yang dijual tersebut disewa kembali oleh penjual sehingga akad bay' wafa' berubah menjadi bay' stighlâl. Bay' stighlâl merupakan jual beli wafa' dengan syarat penjual menyewa kembali barang yang dijualnya dari pembeli. Berdasarkan konsep akad bay' istighlâl,

\footnotetext{
53 Haroen dan Muamalah, Gaya Media Pratama, h. 152.

${ }^{54}$ Haroen dan Muamalah, Gaya Media Pratama, h. 152.

55 Haroen dan Muamalah, Gaya Media Pratama, h. 152.
} 
penerbitan sukuk ijârah yang dikembangkan saat ini tidak lain adalah bay' istighlâl, yaitu akad bay' wafa' yang disertai akad ijârah di dalamnya. Contoh pelaksanaan akad bay' istighlâl ini digunakan dalam penerbitan Surat Berharga Syariah Negara (SBSN) yang dikenal dengan SBSN Ijârah Sale and Lease Back.

\section{Bay Muzâyadah (Jual Beli Lelang)}

Transaksi jual beli sekuritas di pasar modal seperti saham dan sukuk digunakan mekanisme lelang (auction), sering disebut juga sebagai auction market. Akad jual beli selain digunakan pada penerbitan sukuk juga digunakan dalam transaksi sukuk. Adapun mekanisme transaksi jual beli sukuk melalui cara jual beli lelang (auction) atau dalam konsep fikih disebut dengan bay' muzâyadah.

Dalam praktiknya, para calon pembeli itu saling mengajukan harga yang mereka inginkan. Sehingga terjadilah semacam saling tawar dengan suatu harga. Penjual nanti akan menentukan siapa yang menawarkan harga paling tinggi, maka dialah yang berhak menjadi pembeli. Lalu terjadi akad dan pembeli tersebut mengambil barang dari penjual.

Hukum jual beli dengan cara lelang menurut pendapat para ulama, seperti al-Kasni dan Ibnu Human, ulama dari mazhab Hanafi, mengatakan jual beli lelang (al-muzâyadah) tidak dilarang karena Rasulullah Saw. secara pribadi mempraktikkan hal tersebut. Terdapat pendapat ulama yang membolehkan hukum lelang, ada juga yang memakruhkannya karena terdapat sumber hukumnya berbeda. Jumhur (mayoritas ulama) membolehkan lelang, dasarnya adalah apa yang dilakukan langsung oleh Rasulullah Saw. di masa beliau hidup. Hadis yang membolehkannya antara lain:

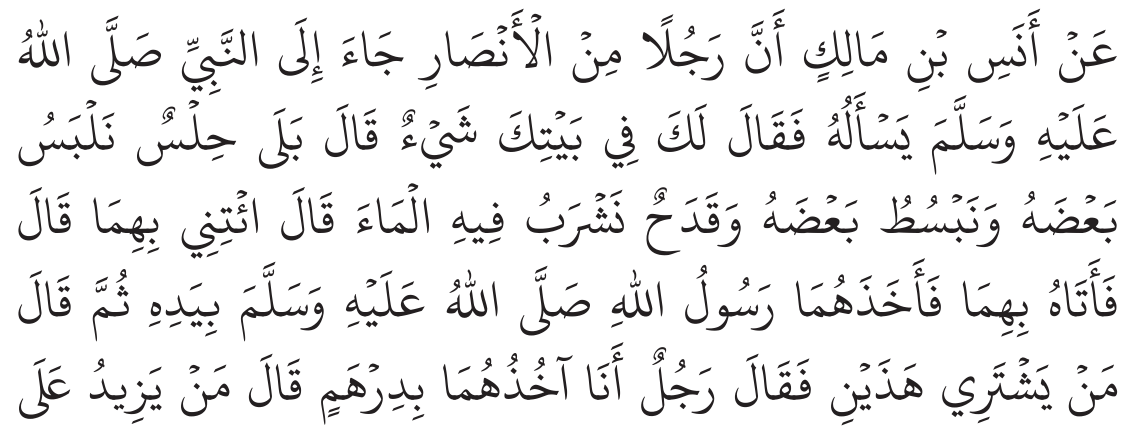




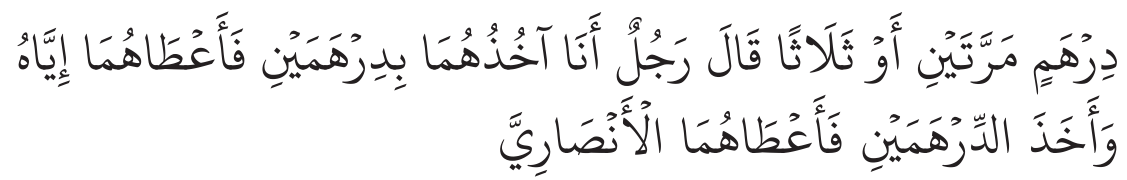

Dari Anas bin Malik ra bahwa ada seorang lelaki Anshar yang datang menemui Nabi saw dan dia meminta sesuatu kepada Nabi Saw. Nabi Saw bertanya kepadanya, "Apakah di rumahmu tidak ada sesuatu?" Lelaki itu menjawab,"Ada. Dua potong kain, yang satu dikenakan dan yang lain untuk alas duduk, serta cangkir untuk meminum air." Nabi Saw berkata, "Kalau begitu, bawalah kedua barang itu kepadaku." Lelaki itu datang membawanya. Nabi Saw bertanya, "Siapa yang mau membeli barang ini?" Salah seorang sahabat beliau menjawab, "Saya mau membelinya dengan harga satu dirham." Nabi saw bertanya lagi, "Ada yang mau membelinya dengan harga lebih mahal?" Nabi Saw menawarkannya hingga dua atau tiga kali. Tiba-tiba salah seorang sahabat beliau berkata, "Aku mau membelinya dengan harga dua dirham." Maka Nabi Saw memberikan dua barang itu kepadanya dan beliau mengambil uang dua dirham itu dan memberikannya kepada lelaki Anshar tersebut. (H.r. Ahmad, Abu Dawud, al-Nasa i, dan al-Tirmidzi).

Praktik perdagangan saham dan sukuk pada pasar modal dilakukan dengan mekanisme al-muzayyadah (lelang). Kontrak muzayadah adalah penawaran sekuritas untuk dijual dengan harga terbaik, kemudian kontrak dilakukan atas salah satu harga yang ditawarkan yakni harga tertinggi.

Proses jual beli lelang dilakukan dengan tawar menawar oleh para peserta lelang. Jika belum ada kesepakatan antar peserta yang melakukan penawaran, maka dimungkinkan orang lain mengajukan tawaran dan memberi tambahan atas harga pertama.Hal itu sesuai dengan hadis yang diriwiyatkan dari Anas: "Sesungguhnya Nabi Saw. pernah menawarkan anak panah dan pelana kepada beberapa sahabatnya. Lalu seorang lakilaki berkata, "Keduanya bagiku dengan harga satu dirham". Kemudian orang yang lain berkata, "Keduanya bagiku dengan dua dirham". (H.r. Bukhâri dan Muslim)..$^{56}$

${ }^{56}$ Muhammad Turmudi, 'Implementasi Akad Percampuran dalam Hukum Ekonomi Syariah', Al-'Adl, 10.2 (2017), h. 33-53. 
Hukum jual beli secara muzâyadah adalah dibolehkan berdasarkan argumentasi pembolehan bay' muzâyadah ${ }^{57}$ seperti yang tercantum dalam hadis tersebut.

\section{Jenis Akad Sukuk di Pasar Modal}

Sukuk (صُكُوكَك) adalah istilah yang berasal dari bahasa Arab dan merupakan bentuk jamak (plural) dari kata 'sakk' (صَكَ), yang berarti dokumenatau sertifikat. Pada pertengahan abad 20, sukuk lazim digunakan oleh para pedagang Muslim sebagai dokumen yang menunjukkan kewajiban finansial yang timbul dari perdagangan dan aktivitas komersial lainnya. ${ }^{58}$

Berdasarkan Standard Syariah The Accounting and Auditing Organization for Islamic Financial Institutions (AAOIFI) No. 17 tentang Investment Sukuk (Sukuk Investasi), Sukuk didefinisikan sebagai sertifikat bernilai sama yang merupakan bukti atas bagian kepemilikan yang tidak terbagi terhadap suatu aset, hak manfaat, dan jasa-jasa, atau atas kepemilikan suatu proyek atau kegiatan investasi tertentu.

Fatwa Dewan Syariah Nasional-Majelis Ulama Indonesia (DSNMUI) No. 32/DSN-MUI/IX/2002 tentang Obligasi Syariah, Sukuk (Obligasi Syariah) didefinisikan sebagai surat berharga jangka panjang berdasarkan prinsip syariah yang dikeluarkan Emiten kepada pemegang obligasi syariah yang mewajibkan Emiten untuk membayar pendapatan kepada pemegang obligasi syariah berupa bagi hasil/margin/fee serta membayar kembali dana obligasi pada saat jatuh tempo. Ada pula yang menyebut sukuk dengan istilah obligasi syariah. Menurut para pakar, obligasi syariah adalah suatu kontrak perjanjian tertulis yang bersifat jangka panjang untuk membayar kembali pada waktu tertentu seluruh kewajiban yang timbul akibat pembiayaan untuk kegiatan tertentu menurut syarat dan ketentuan tertentu serta membayar sejumlah manfaat secara periodik menurut akad.

${ }^{57}$ Eka Nuraini Rachmawati, 'Akad Jual Beli dalam Perspektif Fikih dan Praktiknya di Pasar Modal Indonesia', Al-'Adalah, 12.2 (2015), h. 785-806.

${ }^{58}$ Ayub, Understanding Islamic Finance: A-Z Keuangan Syariah, h. 55. 
Berdasarkan keputusan Ketua Badan Pengawas Pasar Modal dan Lembaga Keuangan (Bapepam-LK) Nomor KEP-181/BL/2009, Sukuk didefinisikan sebagai Efek Syariah berupa sertifikat atau bukti kepemilikan yang bernilai sama dan mewakili bagian penyertaan yang tidak terpisahkan atau tidak terbagi atas:

a. Kepemilikan aset berwujud tertentu

b. Nilai manfaat dan jasa atas asset proyek tertentu atau aktivitas investasi tertentu

c. Kepemilikan atas aset proyek tertentu atau aktivitas investasi tertentu

Dari empat belas jenis akad sukuk yang disetujui AAOIFI, terdapat enam jenis akad yang sering digunakan dalam penerbitan sukuk, yakni :

\section{Sukuk ljârah}

Sukuk ijârah adalah pembiyaan yang menggunakan akad ijârah. Sukuk ijârah dapat juga diartikan sebagai surat berharga yang berisi akadpembiayaan berdasarkan pada prinsip syariah yang dikeluarkan oleh perusahaan (emiten), pemerintah pusat/daerah atau institusi lainnya yang mewajibkan pihak yang mengeluarkannya untuk membayar pendapatan kepada pemegang sukukberupa fee dari hasil pembayaran menyewakan aset serta dibayar kembali dana pokok sukuk pada saat jatuh tempo. ${ }^{59}$ Sukuk ijârah diterbitkan berdasarkan perjanjian atau akad ijârah, di mana satu pihak bertindak sendiri atau melalui wakilnya menyewakan hak manfaat atas suatu aset kepada pihak lain berdasarkan harga dan periode yang disepakati, tanpa diikuti perpindahan kepemilikan aset itu sendiri.

\section{Sukuk Mudhârabah}

Sukuk mudhârabah adalah surat berharga yang berisi akad pembiayaan yang menggunakan sisten akad mudhârabah. Sukuk mudhârabah dapat juga didefinisikan sebagai surat berharga berisi akad pembiayaan berdasarkan pada prinsip syariah yang dikeluarkan oleh perusahaan (emiten),

59 Muhammad Nafik H. R. Ryandono and Indonesia Undang-Undang Tentang Surat Berharga Syariah Negara, Bursa Efek \& Investasi Syariah, Cet. 1 (Jakarta: Serambi, 2009). 
pemerintah atau institusi lainnya yang mewajibkan pihak yang menerbitkannya untuk membayar pendapatan kepada pemegangsukuk berupa bagi hasil dari hasil pengelolahan dana yang telah disetorkan oleh pemilik dana serta dibayar kembali dana pokok sukuk pada saat jatuh tempo. ${ }^{60}$ Sukuk mudhârabah diterbitkan berdasarkan perjanjian atau akad mudhârabah, di mana satu pihak menyediakan modal (rabal-mâl/shâhibul mâl) dan pihak lain menyediakan tenaga dan keahlian (mudharib), keuntungan dari kerjasama tersebut akan dibagi berdasarkan proporsi perbandingan (nisbah) yang disepakati sebelumnya. Kerugian yang timbul akan ditanggung sepenuhnya oleh pihak penyedia modal, sepanjang kerugian tersebut tidak ada unsur moral hazard.

\section{Sukuk Musyârakah}

Sukuk musyârakah adalah surat berharga yang berisi akad pembiayaan yang menggunakan akad musyârakah. Sukuk musyârakah dapat juga didefinisikan sebagai surat berharga yang berisi akad pembiayaan berdasarkan prinsip yang dikeluarkan oleh perusahaan (emiten) pemerintahan atau institusi lainnya yang mewajibkan pihak yang mengeluarkannya untuk membayar pendapatan kepada pemegang sukukberupa bagi hasil dari hasil pengelolaan dana kontribusi dari pihak-pihak yang berakad serta dibayar kembali dana pokok pada saat jatuh tempo. ${ }^{61}$ Sukuk musyârakah diterbitkan berdasarkan perjanjian atau akad musyârakah, di mana dua pihak atau lebih bekerjasama menggabungkan modal untuk membangun proyek baru, mengembangkan proyek yang sudah ada, atau membiayai kegiatan usaha. Keuntungan maupun kerugian yang timbul ditanggung bersama sesuai dengan jumlah partisipasi modal masing-masing pihak.

\section{Sukuk Istishnâ'}

Sukuk istishnâadalah surat berharga yang berisi akad pembiayaan yang menggunakan akad istishnâ.' Sukuk istishnầ dapat juga diartikan sebagai surat berharga yang berisi akad pembiayaan berdasarkan pada

${ }^{60}$ Ryandono dan Negara, Bursa Efek \& Investasi Syariah, h. 357.

${ }^{61}$ Ryandono dan Negara, Bursa Efek \& Investasi Syariah, h. 358. 
prinsip syariah yang dikeluarkan oleh perusahaan (emiten) pemerintahan atau institusi lainnya yang mewajibkan pihak yang mengeluarkannya untuk membayar pendapatan kepada pemegang sukuk berupa bagi hasil dari marjin keuntungan serta dibayar kembali dana pokok sukuk pada saat jatuh tempo. ${ }^{62}$

Definisi sukuk istishnâjuga hampir sama dengan definisi sukuk salam. Pada dasarnya, kedua akad tersebut hampir sama juga. Hanya cara penyerahan pembiayaannya yang membedakannya. Pada akad salam penyerahan pembiayaannya terjadi pada awal akad. Namun jika pada akad istishnâpembayarannya pada akhir periode akad atau secara angsuran. Sukuk istishnầ diterbitkan berdasarkan perjanjian atau akad istishnâ, di mana para pihak menyepakati jual-beli dalam rangka pembiayaan suatu proyek atau barang. Adapun harga, waktu penyerahan dan spesifikasi proyek/barang ditentukan terlebih dahulu berdasarkan kesepakatan.

\section{Sukuk murâbahah}

Sukuk murâbahahadalah surat berharga yang berisi akad pembiayaan yang menggunakan akad murâbahah.Sukuk murâbahahdi perdagangkan di pasar. Sukukmurâbahahdapat juga diartikan sebagai surat berharga yang berisi akad pembiayaan berdasarkan pada prinsip syariah yang dikeluarkan oleh perusahaan (emiten), pemerintah, atau institusi lainnya, yang mewajibkan pihak mengeluarkannya untuk membayar pendapatan kepada pemegang sukuk berupa bagi hasil marjin keuntungan serta dibayar kembali dana pokok sukuk pada saat jatuh tempo ${ }^{63}$

\section{Sukuk Salam}

Sukuk salam adalah surat berharga yang berisi akad pembiyaan yang menggunakan akad salam. Sukuk salam dapat juga diartikan sebagai surat berharga yang berisi akad pembiayaan berdasarkan pada prinsip syariah yang dikeluarkan oleh perusahaan yang mengeluarkannya untuk membayar pendapatan kepada pemegang sukuk. Biasanya berupa bagi

\footnotetext{
${ }^{62}$ Ryandono dan Negara, Bursa Efek \& Investasi Syariah, h. 359.

${ }^{63}$ Ryandono dan Negara, Bursa Efek \& Investasi Syariah, h. 356.
} 
hasil dari marjin keuntungan serta dibayar kembali dana pokok sukuk pada saat jatuh tempo. ${ }^{64}$

Beberapa sukuk yang diterbitkan menjadi sasaran kritikan tajam disebabkan karena keterlibatannya dari bay' al-inah, bay' al-dayn dan sifatsifat landasan non syariah yang membuat sukuk sama dengan obligasi berdasarkan bunga.

Bay' al-inah merupakan penjualan dua kali di mana pinjam dan orang yang meminjam menjual dan kemudian menjual kembali suatu objek di antara mereka sekali untuk tujuan memperoleh uang tunai dan sekali lagi untuk tujuan harga yang lebih tinggi berdasarkan kredit, dengan hasil bersih dari suatu pinjaman dengan bunga.

Menurut aturan syariah, pemegang sukuk secara bersama memiliki risiko terhadap harga aset dan biaya-biaya yang terkait dengan kepemilikan dan bagian dari uang sewanya dengan melakukan sewa pada pengguna tertentu.

Sumber pendapatan (imbal hasil) sukuk dapat dibedakan menjadi tiga jenis, yaitu marjin, fee dan bagi hasil. Sukuk yang pembayaran pendapatannya bersumber dari marjin keuntungan akad jual beli adalahsukuk murabahah, sukuk salam dan sukuk istishna'. Sukuk yang membayarkan pendapatannya bersifat tetap karena bersumber dari pendapatan tetap dari sewa atau fee, yaitu sukuk ijarah. Sukuk yang pembayaran pendapatannya berdasarkan bagi hasil dari hasil yang diperoleh dalam menjalankan usahanya yang dibiayai, yaitu sukuk mudharabah dan sukuk musyarakah. ${ }^{65}$

\section{Praktik Penerbitan Sukuk Korporasi di Pasar Modal Indonesia}

Sejak penerbitan sukuk yang pertama kali pada tahun 2002 oleh PT. Indosat dengan nilai emisi Rp 175 milyar yang saat itu masih menggunakan istilah obligasi syariah, perkembangannya masih tergolong lambat. Setelah 13 tahun berlalu, perkembangan penerbitan sukuk korporasi di Pasar Modal Indonesia baru mencapai 80 emisi sukuk dengan total nilai $14.483,4$ milyar.

${ }^{64}$ Ryandono dan Negara, Bursa Efek \& Investasi Syariah, h. 358-359.

65 Ryandono dan Negara, Bursa Efek \& Investasi Syariah, h. 360-361. 
Dari 80 emisi sukuk tersebut, 41 sukuk masih beredar dengan nilai nominal Rp 8.284 milyar, sisanya 39 sukuk sudah dilunasi dengan total nilai Rp 6.039,4 milyar. Akad yang digunakan untuk keseluruhan penerbitan sukuk korporasi tersebut, hanya menggunakan dua jenis akad, yakni akad Ijarah dan Mudharabah.

Total penerbitan sukuk dengan akad Ijarah 53 emisi sukuk dan sukuk sisanya 27 sukuk menggunakan akad mudharabah. Sampai bulan Juli 2015. Sukuk Mudharabah didominasi oleh sektor keuangan terutama perbankan syariah, sedangkan sukuk Ijarah diterbitkan oleh perusahaan ritel, manufaktur, insfrastruktur. Jumlah emisi sukuk terbanyak menggunakan akad Ijarah 53 emisi dan menggunakan akad Mudharabah 27 emisi sukuk. Penerbitan sukuk korporasi di Indonesia baru menggunakan dua jenis akad saja, yakni akad Ijarah dan akad Mudharabah. Dalam prakteknya, ternyata terdapat perbedaan struktur antara akad Ijarah satu Ijarah lainnya, begitu juga pada akad mudharabah, tergantung kondisi masing-masing penerbit (emiten), yaitu perbedaan aset dasar (underlying asset), penggunaan dana hasil penerbitan sukuk serta akad paling memungkinkan untuk diterapkan pada saat penerbitan. Dari empat puluh delapan (48) penerbitan sukuk yang diterbitkan oleh duapuluh delapan (28) emiten, yang menggunakan akad Mudharabah terdapat 7 struktur dan akad Ijarah menggunakan 12 struktur (model).

\section{Praktik Penerbitan Sukuk Mudharabah}

Penerbitan sukuk korporasi dengan akad mudharabah di Indonesia tidak hanya menggunakan satu struktur sukuk, tetapi menggunakan tujuh struktur mulai dari skema A sampai skema G. Berikut ini contoh skema sukuk mudharabah model A untuk penerbitan Sukuk Mudharabah PT. Bank Syariah Mandiri (2008). 


\section{Gambar 1: Skema Sukuk Mudharabah Model A}

\section{SKEMA SUKUK MUDHARABAH A}

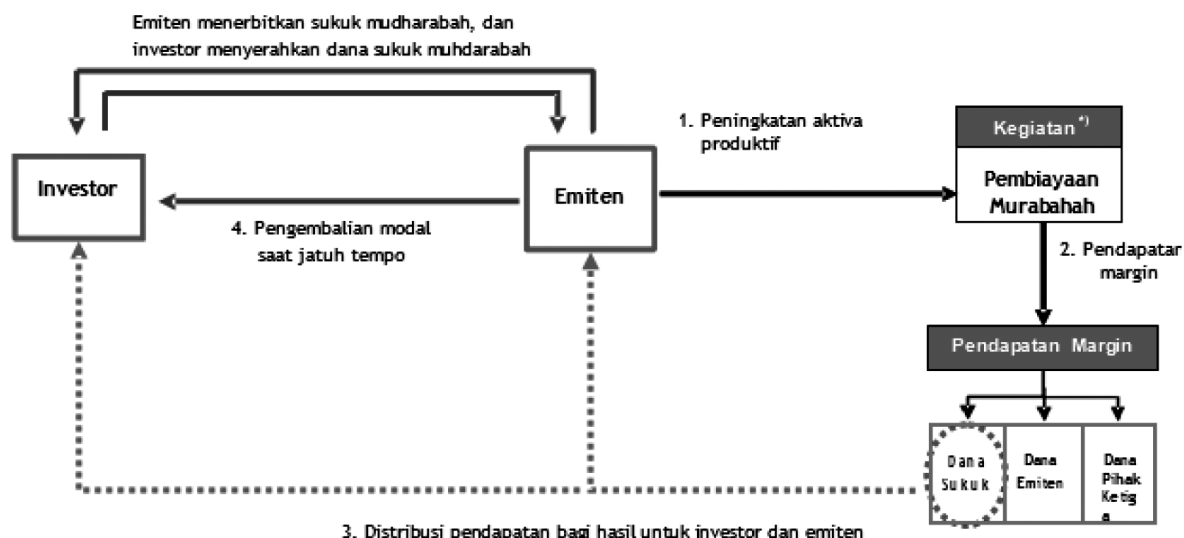

Sumber: Tim Penyusun Himpunan Skema Sukuk (2011)

Rangkuman ke tujuh model Sukuk Mudharabah dirangkum dalam tabel berikut ini:

Tabel 1 : Model Akad Mudharabah pada Penerbitan Sukuk Korporasi

\begin{tabular}{|c|c|c|c|c|}
\hline $\begin{array}{l}\text { Model } \\
\text { Akad Sukuk } \\
\text { Mudharabah }\end{array}$ & Emiten & $\begin{array}{c}\text { Aset Dasar } \\
\text { (Underlyig } \\
\text { Asset) }\end{array}$ & Imbal Hasil & $\begin{array}{c}\text { Tujuan } \\
\text { Penggunaan } \\
\text { Dana }\end{array}$ \\
\hline Model A & $\begin{array}{l}\text { - PT. Bank Syariah } \\
\text { Mandiri (2004) } \\
\text { - PT. Bank } \\
\text { Muamalat } \\
\text { Indonesia (2008) }\end{array}$ & $\begin{array}{l}\text { Pendapatan } \\
\text { Proyek } \\
\text { Pembiayaan } \\
\text { aset } \\
\text { murabahah. }\end{array}$ & $\begin{array}{l}\text { Nisbah } \\
\text { bagi hasil } \\
\text { dari margin } \\
\text { murabahah } \\
\text { yang } \\
\text { dipeloreh. }\end{array}$ & $\begin{array}{l}\text { Meningkatkan } \\
\text { aktiva produktif } \\
\text { yang akan } \\
\text { disalurkan } \\
\text { untuk } \\
\text { pembiayaan } \\
\text { murabahah. }\end{array}$ \\
\hline Model B & $\begin{array}{l}\text { - PT. BPD } \\
\text { Sumatera Barat } \\
(2010) \\
\text { - PT. Bank } \\
\text { Bukopin (2003) }\end{array}$ & $\begin{array}{l}\text { Pendapatan } \\
\text { Proyek } \\
\text { Pembiayaan } \\
\text { aset } \\
\text { Murabahah } \\
\text { dan kegiatan } \\
\text { UUS lainnya. }\end{array}$ & $\begin{array}{l}\text { Nisbah } \\
\text { bagi hasil } \\
\text { dari margin } \\
\text { Murabahah } \\
\text { yang } \\
\text { dipeloreh }\end{array}$ & $\begin{array}{l}\text { Untuk } \\
\text { pengembangan } \\
\text { usaha berupa } \\
\text { pembiayaan } \\
\text { syariah yang } \\
\text { dilakukan Unit } \\
\text { Usaha Syariah } \\
\text { emiten. }\end{array}$ \\
\hline
\end{tabular}




\begin{tabular}{|c|c|c|c|c|}
\hline Model C & $\begin{array}{l}\text { - PT. Mayora } \\
\text { (2008) }\end{array}$ & $\begin{array}{l}\text { Pendapatan } \\
\text { Kegiatan } \\
\text { Usaha } \\
\text { (produksi/ } \\
\text { kontrak } \\
\text { penjualan) } \\
\text { emiten. }\end{array}$ & $\begin{array}{l}\text { Nisbah bagi } \\
\text { hasil tunggal } \\
\text { dari kontrak } \\
\text { penjualan. }\end{array}$ & $\begin{array}{l}\text { Untuk } \\
\text { penambahan } \\
\text { kapasitas } \\
\text { produksi dan } \\
\text { modal kerja. }\end{array}$ \\
\hline Model D & $\begin{array}{l}\text { - PT. Cilandra } \\
\text { Perkasa (2003) }\end{array}$ & $\begin{array}{l}\text { Pendapatan } \\
\text { produksi / } \\
\text { kontrak } \\
\text { penjualan } \\
\text { anak } \\
\text { perusahaan }\end{array}$ & $\begin{array}{l}\text { Nisbah } \\
\text { bagi hasil } \\
\text { tunggal dari } \\
\text { pendapatan } \\
\text { anak } \\
\text { perusahaan. }\end{array}$ & $\begin{array}{l}\text { Untuk } \\
\text { pembangunan } \\
\text { pabrik anak } \\
\text { perusahaan. }\end{array}$ \\
\hline Model E & $\begin{array}{l}\text { - PT. Perkebunan } \\
\text { NegaraVII } \\
(2004)\end{array}$ & $\begin{array}{l}\text { Pendapatan } \\
\text { penjualan } \\
\text { komoditas }\end{array}$ & $\begin{array}{l}\text { Nisbah bagi } \\
\text { hasil bersifat } \\
\text { multinisbah } \\
\text { (menurun) } \\
\text { dari } \\
\text { pendapatan } \\
\text { penjualan } \\
\text { komoditas } \\
\text { dikurangi } \\
\text { biaya. }\end{array}$ & $\begin{array}{l}\text { Untuk } \\
\text { peningkatan } \\
\text { kapasitas } \\
\text { produksi } \\
\text { dan sarana } \\
\text { pendukung. }\end{array}$ \\
\hline Model F & $\begin{array}{l}\text { - PT. Adhi } \\
\text { Karya(2007) }\end{array}$ & $\begin{array}{l}\text { Pendapatan } \\
\text { proyek } \\
\text { kerja sama } \\
\text { penjualan } \\
\text { usaha jasa } \\
\text { konstruksi } \\
\text { atas satu atau } \\
\text { lebih proyek } \\
\text { yang sedang } \\
\text { dan akan } \\
\text { dikerjakan }\end{array}$ & $\begin{array}{l}\text { Nisbah bagi } \\
\text { hasil tunggal } \\
\text { dari laba } \\
\text { kotor dari } \\
\text { pendapatan } \\
\text { proyek. }\end{array}$ & $\begin{array}{l}\text { Untuk modal } \\
\text { penyelesaian } \\
\text { proyek proyek } \\
\text { yang sedang } \\
\text { dan akan } \\
\text { dikerjakan. }\end{array}$ \\
\hline Model G & $\begin{array}{l}\text { - PT.Indosat(2002) } \\
\text { - PT.Berlian Laju } \\
\text { Tanker (2003) }\end{array}$ & $\begin{array}{l}\text { Pendapatan } \\
\text { yang } \\
\text { diperoleh atas } \\
\text { pengoperasian } \\
\text { objek (satelit } \\
\text { dan kapal } \\
\text { tanker) }\end{array}$ & $\begin{array}{l}\text { Nisbah bagi } \\
\text { hasil dari } \\
\text { pendapatan } \\
\text { yang } \\
\text { diperoleh atas } \\
\text { pengoperasian } \\
\text { objek }\end{array}$ & $\begin{array}{l}\text { Untuk } \\
\text { pengembangan } \\
\text { usaha bisnis } \\
\text { emiten. }\end{array}$ \\
\hline
\end{tabular}

Sumber: Tim Penyusun Himpunan Skema Sukuk (2011) \& Andri.S (2014) 


\section{Praktik Penerbitan Sukuk ljarah}

Praktik penerbitan Sukuk Ijarah di Pasar Modal Indonesia menggunakan dua belas struktur (modal). Contoh skema penerbitan sukuk Ijarah dengan model A untuk penerbitan Sukuk Ijarah. PT. Aneka Gas Industri I Tahun 2008.

Gambar 2: Skema Sukuk Ijarah A

SKEMA SUKUK IJARAH $A^{m * n}$ )

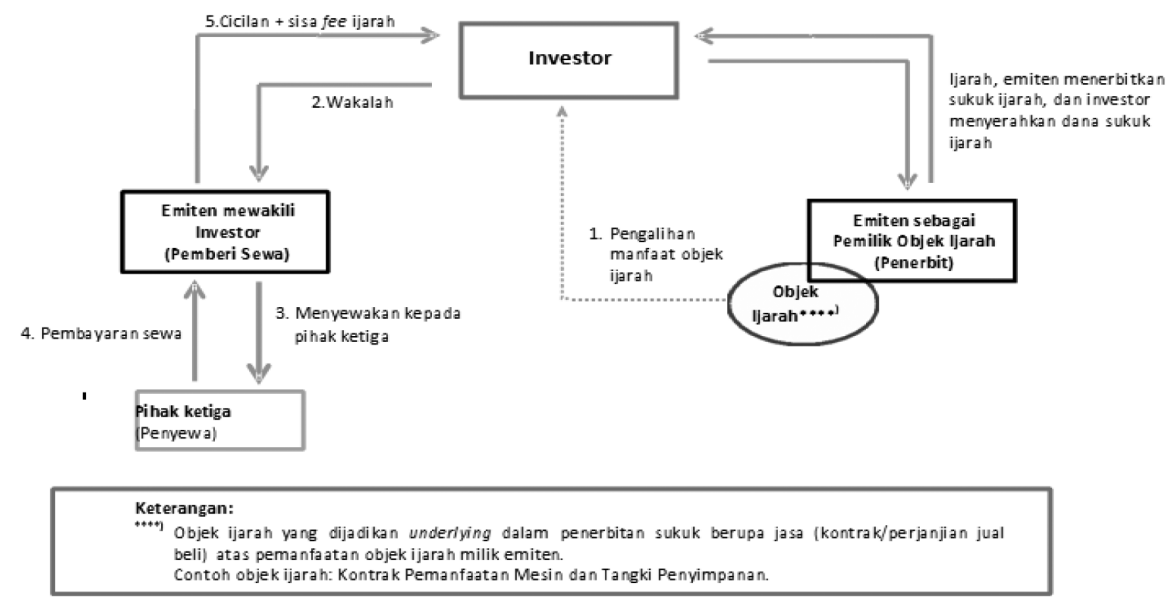

Sumber: Tim Penyusun Himpunan Skema Sukuk (2011)

Tabel 2: Rangkuman Model Akad Ijarah pada Penerbitan Sukuk Korporasi

\begin{tabular}{|c|c|c|}
\hline $\begin{array}{l}\text { Model Akad } \\
\text { Sukuk Ijârah }\end{array}$ & Emiten & Aset Dasar (Underlying Asset) \\
\hline Model A1 & $\begin{array}{l}\text { - PT. Humpus Intermoda } \\
\text { Transportasi (2004) } \\
\text { - PT. Apexindo Pratama Duta } \\
\text { (2005) } \\
\text { - PT. PLN (2006,2009, 2010) } \\
\text { - PT. Berlian Laju Tanker (2007, } \\
\text { 2009) } \\
\text { - PT. Indosat(2005, 2007, 2008, } \\
\text { 2009) } \\
\text { - PT. Sumercon Agung (2008) } \\
\text { - PT. Metro Data Electronics } \\
\text { (2008) }\end{array}$ & $\begin{array}{l}\text { Obyek Ijârah yang dijadikan aset } \\
\text { dasar dalam penerbitan sukuk } \\
\text { berupa aset tetap milik emiten baik } \\
\text { yang sudah ada dengan jenis aset } \\
\text { dan spesifikasi yang jelas. Contoh } \\
\text { objek Ijârah: Kapal Tanker dengan } \\
\text { bobot mati tertentu, jaringan } \\
\text { listrik dengan jenis, nilai dan } \\
\text { spesifikasi tertentu, bangunan } \\
\text { yang berfungsi sebagai mall, sirkit } \\
\text { dengan kapasitas tertentu. }\end{array}$ \\
\hline
\end{tabular}




\begin{tabular}{|c|c|c|}
\hline $\begin{array}{l}\text { Model Akad } \\
\text { Sukuk Ijârah }\end{array}$ & Emiten & Aset Dasar (Underlying Asset) \\
\hline Model A2 & - PT. CSM Corporatama (2009) & $\begin{array}{l}\text { Aset tetap milik emiten, yaitu } \\
\text { sekumpulan aset tetap yang } \\
\text { sudah ada maupun belum ada. } \\
\text { Contoh objek Ijârah: Kendaraan }\end{array}$ \\
\hline Model A3 & - PT. Aneka Gas Industri(2009) & $\begin{array}{l}\text { Objek Ijârah berupa jasa } \\
\text { (kontrak /perjanjian jual beli) } \\
\text { atas pemanfaatan objek ijarah } \\
\text { milik emiten. Contoh: Mesin } \\
\text { dan Tangki Penyimpanan }\end{array}$ \\
\hline Model A4 & - PT. Mitra Adiperkasa (2009) & $\begin{array}{l}\text { Aset tetap milik emiten, yaitu } \\
\text { sekumpulan aset tetap yang } \\
\text { sudah ada maupun belum ada. } \\
\text { Contoh objek Ijârah: Kendaraan }\end{array}$ \\
\hline Model B1 & $\begin{array}{l}\text { - PT. Matahari Putra Prima } \\
\text { (2004, 2009) } \\
\text { - PT. PLN (2007) }\end{array}$ & $\begin{array}{l}\text { Aset tetap milik pihak ketiga yang } \\
\text { sudah ada dengan jenis aset dan } \\
\text { spesifikasi yang jelas. Contoh } \\
\text { objek Ijârah: Mesin Pembangkit } \\
\text { Listrik Tenaga Diesel, Ruangan } \\
\text { Usaha. }\end{array}$ \\
\hline Model B2 & $\begin{array}{l}\text { - PT. Salim Ivomas Pratama } \\
\text { (2009) } \\
\text { - PT. Pupuk Kalimantan Timur } \\
\text { (2009) }\end{array}$ & $\begin{array}{l}\text { Obyek Ijârah yang dijadikan } \\
\text { underlying aset dalam penerbitan } \\
\text { sukuk berupa jasa milik pihak } \\
\text { ketiga. Contoh: Jasa Pengangkutan }\end{array}$ \\
\hline Model C & $\begin{array}{l}\text { - PT. Titan Petrokimia } \\
\text { Nusantara(2010) }\end{array}$ & $\begin{array}{l}\text { Aset tetap milik emiten, yaitu } \\
\text { sekumpulan aset tetap yang } \\
\text { sudah ada. Contoh objek: Tanah, } \\
\text { Bangunan }\end{array}$ \\
\hline Model D1 & - PT. Berlina (2004) & $\begin{array}{l}\text { Aset tetap milik emiten, yaitu } \\
\text { sekumpulan aset tetap yang } \\
\text { sudah ada. Contoh objek: Tanah, } \\
\text { Bangunan, Mesin. }\end{array}$ \\
\hline Model D2 & $\begin{array}{l}\text { - PT. Ricky Putra Globalindo } \\
\text { (2005) }\end{array}$ & $\begin{array}{l}\text { Aset tetap yang akan dibeli emiten, } \\
\text { dengan menggunakan dana hasil } \\
\text { penawaran sukuk. Contoh objek: } \\
\text { Tanah, Bangunan, Mesin }\end{array}$ \\
\hline Model E & - PT. Citra Sari Makmur (2004) & $\begin{array}{l}\text { Aset tetap milik emiten, yaitu } \\
\text { sekumpulan aset tetap yang sudah } \\
\text { ada. Contoh objek: Peralatan } \\
\text { Jaringan Telekomunikasi. }\end{array}$ \\
\hline
\end{tabular}




\begin{tabular}{lcl}
\hline $\begin{array}{l}\text { Model Akad } \\
\text { Sukuk Ijârah }\end{array}$ & \multicolumn{1}{c}{ Emiten } & Aset Dasar (Underlying Asset) \\
\hline Model F & - PT. Sona Topas Tourism & Aset tetap milik anak perusahaan \\
& Industry (2004) & $\begin{array}{l}\text { yang sudah ada dengan jenis aset } \\
\text { dan spesikasi yang jelas. Contoh } \\
\text { objek Ijârah: Mall. }\end{array}$ \\
\hline Model G & - PT. Bakrieland & Aset tetap milik anak perusahaan \\
& Development(2009) & $\begin{array}{l}\text { yang sudah ada dengan jenis aset } \\
\text { dan spesikasi yang jelas. Contoh } \\
\text { objek Ijârah: Edutainment Mall. }\end{array}$ \\
& & (2011) \& And
\end{tabular}

Sumber: Tim Penyusun Himpunan Skema Sukuk (2011) \& Andri.S (2014)

\section{Penutup}

Dalam dunia bisnis, akad memiliki peranan sangat penting karena keberlangsungan kegiatan bisnis ke depan akan tergantung seberapa baik dan rinci akad yang dibuat untuk menjaga dan mengatur hak dan kewajiban kedua belah pihak. Akad merupakan perjanjian yang mengikat hubungan kedua pihak itu sekarang dan yang akan datang. Pemilihan akad akan mencerminkan seberapa besar tingkat risiko dan keuntungan bagi kedua pihak, terutama bagi pihak pemodal maupun pihak yang mengelola bisnis atau antara pembeli dengan penjual. Tidak semua akad yang terdapat dalam keuangan syariah dapat diimplementasikan di Pasar Modal Syariah khususnya akad yang digunakan dalam penerbitan sukuk. AAOIFI menetapkan empat belas jenis akad yang digunakan untuk menerbitkan sukuk, akan tetapi terdapat enam jenis akad yang sering digunakan dalam penerbitan sukuk di dunia, yaitu akad Mudhârabah, Musyârakah, Ijârah, Salam, Istishnâ dan akad Murâbahah. Selain itu, akad jual beli (bay') juga digunakan sebagai landasan penerbitan sukuk negara, yakni akad bay wafa' dan bay' istighlâl. Akad bay' juga dipraktikkan pada transaksi jual beli sukuk di Pasar sekunder menggunakan akad bay' muzayyadah. Saat ini penerbitan sukuk korporasi di Pasar Modal Indonesia baru menggunakan dua jenis akad yakni, akad Mudhârabah dan Ijârah. Setiap akad menggunkan banyak struktur (skema) sehingga walaupun akadnya sama namun dengan skema (model) yang berbeda. Perbedaan skema dalam penerbitan sukuk tersebut tergantung kondisi 
perusahaan, aset dasar (underlying asset), tujuan penggunaan dana sukuk serta penetapan akad yang memungkinkan pada saat sukuk diterbitkan. Pada saat Indonesia baru menerbitkan empat puluh delapan (48) Sukuk Korporasi, sukuk Mudharabah telah menggunakan tujuh skema (model) dan sukuk Ijarah mengunakan dua belas skema (model). Di masa yang akan datang penerbitan sukuk korporasi mestinya memiliki struktur akad yang standard sehingga lebih seragam dan tetap memenuhi aspek kepatuhan syariahnya.

\section{Pustaka Acuan}

Al-Khin, Mustafa, Mustada al-Bugha, and Ali al-Sharbaji, Al-Fiqh AlManhaji: Ala Mazhab Al-Imam Al-Syafi'i. Dar al-Syamiah, 1996.

Andriansyah, Yuli. "Kinerja Keuangan Perbankan Syariah di Indonesia dan Kontribusinya Bagi Pembangunan Nasional.” La_Riba 3, no. 2 (2009): 181-196.

Askar, S., Kamus Arab-Indonesia: Al-Azhar, Terlengkap, Mudah \& Praktis. Senayan Pub., 2009.

Asaad, Mhd. "Peningkatan Peranan Perbankan Syariah Untuk Pembiayaan Usaha Pertanian.” MIQOT: Jurnal Ilmu-ilmu Keislaman 35, no. 1 (2011).

Arianto, Dwi Agung Nugroho. "Peranan Al-Mudharabah sebagai Salah Satu Produk Perbankan Syariah dalam Upaya Mengentaskan Kemiskinan di Indonesia." Jurnal Ekonomi \& Pendidikan 8, no. 2 (2011).

Al-Amine, Muhammad Al-Bashir Muhammad. "Istisna and Its Application In Islamic Banking.” Arab Law Quarterly 22 (2001): 22ą48.

Affandi, Anas. "Makna Pembiayaan Salam Perspektif Perbankan Syariah dan Petani di Probolingo." Jurnal Ilmiah Mahasiswa FEB 2, no. 2 (2013). Adnan, Muhammad Akhyar. "Faktor-Faktor yang Mempengaruhi Belum Diaplikasikannya Akad Salam pada Perbankan Syariah (Studi pada 3 BPRS Yogyakarta) dan Kaitannya dengan Pengurangan Tingkat Kemiskinan.” International Conference On Islamic Economics And Financial Inclution (ICIEFI) UMY, 2015.

Arifin, Sirajul. "Musyârakah: Antara Fikih dan Perbankan Syariah.” MIQOT: Jurnal Ilmu-ilmu Keislaman 36, no. 1 (2016). 
Alifi, Wahyu. "Pelaksanaan Akad Musyârakah Mutanâqishah dalam Pembiayaan Perumahan pada Bank Muamalat Cabang Malang." PhD diss., Universitas Islam Negeri Maulana Malik Ibrahim, 2012. Arwani, Agus. "Studi Kritis Akad Pembiayaan Musyârakah pada Perbankan Syari'ah.” Jurnal Hukum Islam (2016).

Ayub, Muhammad, Understanding Islamic Finance: A-Z keuangan syariah (PT Gramedia Pustaka Utama, 2007)

Az-Zuhaili, Wahbah, 'Fiqh Islam Wa Adillatuhu, Jilid 10'. Jakarta: Gema Insani, 2011

Dahlan, Abdul Aziz, 'Ensiklopedi Hukum Islam'. Jakarta: Ichtiar Baru Van Hoeve, 1996

Djamil, Fathurraman, 'Aplikasi Pasar Sukuk dalam Perspektif Syariah (Studi Analisis Kesesuaian Syariah Terhadap Aplikasi Pasar Sukuk Domestik dan Global)', 2012.

Faozi, Moh Mabruri, and Putri Inggi Rahmiyanti, 'Sistem Pengupahan Tenaga Kerja Home Industriperspektif Ekonomi Islam', Al-Mustashfa: Jurnal Penelitian Hukum Ekonomi Syariah, 4 (2016)

Ghani, Ab Mumin Ab, Sistem Kewangan Islam dan Pelaksanaannya di Malaysia. Jabatan Pengajian Islam, Fakulti Sastera dan Sains Sosial, Universiti Malaya, 1997.

Ghani, Eka Nuraini Rachmawati \& Ab Mumin bin Ab, 'Akad Jual Beli dalam Perspektif Fikih dan Praktiknya di Pasar Modal Indonesia', Al-'Adalah, 12 (2015), 785-806 <https://doi.org/10.24042/adalah. v12i2.214>

Haroen, Nasrun, and Fiqh Muamalah, Gaya Media Pratama (Jakarta, 2007)

Kara, Muslimin. "Konstribusi Pembiayaan Perbankan Syariah Terhadap Pengembangan Usaha Mikro Kecil dan Menengah (UMKM) di Kota Makasar." 47, no. 1 (2013).

Khairuddin, Abdul Rashid, Kobayashi Kiyoshi, and Hasan Sharina Farihah, Concept And Application Of Shariah For The Construction Industry: Shariah Compliance In Construction Contracts, Project Finance And Risk Management. World Scientific, 2018. 
Kusmiyati, Asmi Nur Siwi. "Risiko Akad dalam Pembiayaan Murabahah pada BMT di Yogyakarta (dari Teori ke Terapan).” La_Riba 1, no. 1 (2007): 27-41.

Mughniyah, Muhammad Jawad, Fiqih Lima Mazhab: Ja'fari, Hanafi, Maliki, Syafi'i, Hambali. Shaf, 2015.

Munawwir, Ahmad Warson, 'Kamus Al-Munawwir Arab-Indonesia Terlengkap', Surabaya: Pustaka Progressif, 1997

Muslich, Ahmad Wardi, 'Fiqh Muamalat, Cet. Ke-1', Jakarta: Amzah, 2010

Mujiatun, Siti. "Jual Beli dalam Perspektif Islam: Salam dan Istisna'." JRAB: Jurnal Riset Akuntansi \& Bisnis 13, no. 2 (2014).

Musfiroh, Mila Fursiana Salma. "Musyârakah dalam Ekonomi Islam (Aplikasi Musyârakah dalam Fiqih dan Perbankan Syariah).” Syariati: Jurnal Studi Al-Qur'an dan Hukum 2, no. 01 (2016): 173-185.

Permata, Russely Inti Dwi. "Analisis Pengaruh Pembiayaan Mudharabah dan Musyarakah Terhadap Tingkat Profitabilitas (Return On Equity) (Studi pada Bank Umum Syariah Yang Terdaftar di Bank Indonesia Periode 2009-2012)." Jurnal Administrasi Bisnis 12, no. 1 (2014).

Prastiawati, Fitriani, and Emile Satya Darma. "Peran Pembiayaan Baitul Maal Wat Tamwil Terhadap Perkembangan Usaha dan Peningkatan Kesejahteraan Anggotanya dari Sektor Mikro Pedagang Pasar Tradisional." Jurnal Akuntansi dan Investasi 17, no. 2 (2016): 197208.

Prabowo, Bagya Agung. "Konsep Akad Murabahah Pada Perbankan Syariah (Analisa Kritis Terhadap Aplikasi Konsep Akad Murabahah di Indonesia dan Malaysia)." Jurnal Hukum IUS QUIA IUSTUM 16, no. 1 (2009): 106-126.

Qomariyah, Nurul, and Iwan Triyuwono. "Penentuan Margin Akad Murabahah pada Bank Muamalat Indonesia Cabang Malan.” Jurnal Ilmiah Mahasiswa FEB 2, no. 2 (2013).

Rachmawati, Eka Nuraini, 'Akad Jual Beli dalam Perspektif Fikih dan Praktiknya di Pasar Modal Indonesia', Al-'Adalah, 12.2 (2016), 785-806. 
Roziq, Ahmad, Nur Hisamuddin, Nining Ika Wahyuni, and Indah Purnamawati. "Model Pembiayaan Salam pada Petani Singkong dan Usaha Kecil Berbahan Singkong di Kabupaten Jember.” Jurnal Akuntansi Universitas Jember 12, no. 2 (2014).

Ryandono, Muhammad Nafik H. R., and Indonesia Undang-Undang Tentang Surat Berharga Syariah Negara, Bursa Efek \& Investasi Syariah, Cet. 1. Jakarta: Serambi, 2009.

Rejeki, Fanny Yunita Sri. "Akad Pembiayaan Murabahah dan Praktiknya Pada PT Bank Syariah Mandiri Cabang Manado.” Lex Privatum 1, no. 2 (2013).

Sula, Atik Emilia. "Reformulasi Akad Pembiayaan Murabahah dengan Sistem Musyarakah Sebagai Inovasi Produk Perbankan Syariah." Makalah Disampaikan pada Simposium Nasional Akuntansi XII di Universitas Jendral Soedirman, Purwokerto (2010).

Sayyid, Nor Hasanuddin, Aisyah Saipuddin, and Johari al-Yamani, Figh Al-Sunnah. Dâr al-Rayyân lil-Turâth, 1990.

Sa'di, Abdurrahman, Fiqih Jual Beli: Panduan Praktis Bisnis Syariah. Senayan Publishing, 2008.

Sahrani, Sohari, 'Ru’fah Abdullah', Fikih Muamalah, 2011.

Shihab, M. Quraish, Tafsir Al-Mishbah: Pesan, Kesan, dan Keserasian AlQur'an. Ciputat: Lentera Hati, 2000.

Sholihin, Ahmad Ifham, Buku Pintar Ekonomi Syariah. Jakarta: Gramedia Pustaka Utama, 2013.

Setiawan, Aziz Budi. "Perbankan Syariah; Challenges dan Opportunity Untuk Pengembangan di Indonesia.” Jurnal Kordinat 8, no. 1 (2006).

Tahir, Masnun, 'Pemikiran T. M. Hasbi Ash-Shiddieqy: Sumber Hukum Islam dan Relevansinya dengan Pemikiran Hukum Islam di Indonesia', Al-Ahwal: Jurnal Hukum Keluarga Islam, 1 (2016), 117-52

Turmudi, Muhammad, 'Implementasi Akad Percampuran dalam Hukum Ekonomi Syariah', Al-'Adl, 10 (2017), 33-53

Wahid, Nazaruddin Abdul, Sukuk: Memahami \& Membedah Obligasi Pada Perbankan Syariah. Ar-Ruzz Media, 2010. 